\title{
Cancer vs. SARS-CoV-2 induced inflammation, overlapping functions, and pharmacological targeting
}

\author{
Sreedhar Amere Subbarao ${ }^{1}$ (i) \\ Received: 28 September 2020 / Accepted: 27 February 2021 / Published online: 15 March 2021 \\ (c) The Author(s), under exclusive licence to Springer Nature Switzerland AG 2021
}

\begin{abstract}
Inflammation is an intrinsic defence mechanism triggered by the immune system against infection or injury. Chronic inflammation allows the host to recover or adapt through cellular and humoral responses, whereas acute inflammation leads to cytokine storms resulting in tissue damage. In this review, we present the overlapping outcomes of cancer inflammation with virus-induced inflammation. The study emphasises how anti-inflammatory drugs that work against cancer inflammation may work against the inflammation caused by the viral infection. It is established that the cytokine storm induced in response to SARS-CoV-2 infection contributes to disease-associated mortality. While cancer remains the second among the diseases associated with mortality worldwide, cancer patients' mortality rates are often observed upon extended periods after illness, usually ranging from months to years. However, the mortality rates associated with COVID-19 disease are robust. The cytokine storm induced by SARS-CoV-2 infection appeared to be responsible for the multi-organ failure and increased mortality rates. Since both cancer and COVID-19 disease share overlapping inflammatory mechanisms, repurposing some anticancer and anti-inflammatory drugs for COVID-19 may lower mortality rates. Here, we review some of these inflammatory mechanisms and propose some potential chemotherapeutic agents to intervene in them. We also discuss the repercussions of anti-inflammatory drugs such as glucocorticoids and hydroxychloroquine with zinc or antiviral drugs such as ivermectin and remdesivir against SARS-CoV-2 induced cytokine storm. In this review, we emphasise on various possibilities to reduce SARS-CoV-2 induced cytokine storm.
\end{abstract}

Keywords Cancer $\cdot$ SARS-CoV-2 $\cdot$ COVID-19 $\cdot$ Inflammation $\cdot$ Cytokines

\section{Immune system}

The word "immune" indicates resistance developed by the host system to toxic compounds, foreign particles, and infections from the microorganisms (Parkin and Cohen 2001; Medzhitov 2007; Chaplin 2010). In gross terms, immunity refers to a host defence mechanism, which is thought to have advanced with the evolution. While unicellular organisms are equipped with specific enzymes and inhibitors to distinguish and eliminate non-self from self, the multi-cellular organisms involve cells, tissues, and blood for this purpose. Due to increased cellular complexity, vertebrates exhibit coordinated cellular defence functions involving different immune cells (Danilova 2006; Boehm and Swann 2014).

Sreedhar Amere Subbarao

assr@ccmb.res.in

1 CSIR-Centre for Cellular and Molecular Biology, Uppal Road, Hyderabad 500007, India
The lymphocytes go through clonal selection and expansion to produce a subgroup of immunoglobulins to act against foreign bodies or antigens (Cooper and Alder 2006; Schroeder and Cavacini 2010). The T-cells regulate innate immune response while B-cells regulate adaptive immune response (Kaufmann 2019).

\section{Cancer immunity}

Cancer is a disease of uncontrolled cell proliferation, which primarily emerges from acquired genetic mutations and epigenetic alterations in oncogenes and tumour suppressors upon exposure to viral counterparts, UV irradiation, and carcinogens (Butel 2000; Gaglia and Munger 2018; Pfeifer 2020). The cells harboring these mutations get adapted while bypassing the host immune response (Costello et al. 1999; Seliger 2005). Like cell cycle checkpoints that are deregulated in cancers to facilitate uncontrolled cell proliferation 
(Hanahan and Weinberg 2011), the altered immune checkpoints take care of anticancer immunity (Vinay and Kwon 2018). It could be the reason, in addition to targeting the signal transduction pathways that are identified as signatures of cancer (Bild et al. 2006), the monoclonal antibodies (MABs) and their conjugates against mutated gene products appear to act against tumours (Adams and Weiner 2005). The anticancer immune response is also associated with induced inflammatory response and benefits cancer survival and spread (Balkwill 2006; Mantovani et al. 2008). The chronic inflammation caused by cancer cells can trigger neoplastic transformation in the bystander cells (Coussens and Werb 2002; Greten and Grivennikov 2019). The elevated inflammatory responses are associated with increased cytokine levels, contributing to cancer progression (Chen and Mellman 2013; D'Elia et al. 2013). Therefore, interfering with the cytokine response is considered an alternate or adjuvant anticancer treatment strategy (Yao et al. 2014; Nakamura and Smyth 2017).

\section{Cancer by viral infections}

Many viral infections in the host are propagated by hijacking the host defence machinery. Viral infections can induce mutations in the regulatory proteins such as oncogenes and tumour suppressors. It is established that many RNA (Butel 2000) or DNA (Fey and Larsen 1988) virus infections, such as human papilloma (HPV) (Araldi et al. 2018), human immunodeficiency syndrome virus (HIV) (Yarchoan and Uldrick 2018), Kaposi's sarcoma-associated herpesvirus (KSHV) (Gonçalves et al. 2017), hepatitis C virus (HCV) (Benkheil et al. 2018), human polyomavirus (JCV) (Delbue et al. 2017), and hepatitis B virus (HBV) (Levrero and Zucman-Rossi 2016) infections, can cause cancers (Fig. 1). The most common viral infection by HPV is shown to cause age-related cancer progression in women indicating that the compromised immune system is permissive to virus spread (Castellsagué 2008). Consequently, old age has been identified as a risk factor for cancer (White et al. 2014a). The Adenovirus (McAllister et al. 1972) and SV40 polyomavirus (Poulin and DeCaprio 2006) are also shown to cause cancers.

\section{Mechanisms of virus-induced cancer}

Both RNA and DNA viruses can cause cancer in the host. The viral genes can permanently incorporate into the host genome and facilitate deregulated cellular mechanisms favouring tumour growth (Vogt et al. 1997; Temin and Mizutani 1970). Among the two classes of viruses, the transforming virus will have a proto-oncogenic counterpart, and

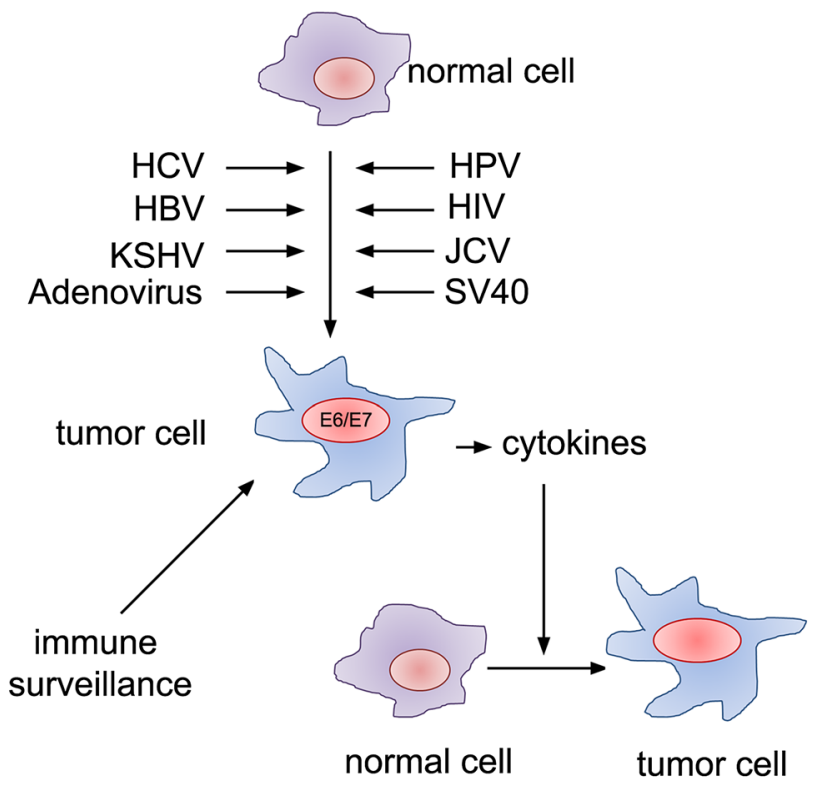

Fig. 1 Virus-induced neoplastic cellular transformation. The RNA (HCV) and DNA (HBV, HPV, HIV, JCV, SV40, KSHV, Adenovirus) viruses can infect normal cells and induce cellular transformation. The virus can either introduce mutation in the protooncogene or introduce viral genes such as E6/E7 to regulate uncontrolled cell proliferation leading to neoplastic transformation. The secretory cytokines produced by these cancer cells can trigger inflammatory responses to facilitate cellular transformation in normal cells. Therefore, the chronic cytokine response contributes to tumour progression, where host immunosurveillance decides its outcome

upon mutation, it can transduce into host cells to induce cellular transformation, whereas non-transforming virus can introduce a strong viral promoter or viral gene into the host cell to trigger the transcription of growth promoting factors (Fan 2011; Vogt 2012). The RNA and DNA viruses are dependent on host transcriptional machinery for their propagation (Butel 2000; Bagga and Bouchard 2014). Many human tumours are linked to viral infections (Dayaram and Marriott 2008; Gatza et al. 2005). In addition to genetic alterations within oncogenes and tumour suppressor genes, virus-induced cancers also arise from the epigenetic crosstalk (Poreba et al. 2011; White et al. 2014b).

\section{Immune modulation and role of cytokines}

The T-lymphocytes and B-lymphocytes play vital roles in regulating innate and adaptive immunity. The T-lymphocytes are the primary source of cytokines. While $\mathrm{T}$ cells are produced from the bone marrow, their maturation takes place at the thymus. These cells are classified into helper (with CD4 co-receptor), cytotoxic (with CD8 co-receptor), and regulatory ( $\mathrm{T}-\mathrm{Reg}$ ) $\mathrm{T}$ cells. The helper $\mathrm{T}$ cells trigger cytokine production in response to antigens presented by 
MHC Class II and antigen-presenting cells (APCs). These cytokines subsequently trigger B cell differentiation to produce antibodies (Roche and Furuta 2015). In contrast, cytotoxic $\mathrm{T}$ cells receive antigens from MHC Class I, become the effector cells, and directly kill the infected cells or cancer cells (Hewitt 2003). The ability of the thymus decreases with age. Therefore, old age appears to be a risk factor for virus infections and cancer (Shaw et al. 2013; White et al. 2014a). The cytokines are glycopeptides and act as humoral regulators at low concentrations (picomolar or nanomolar concentrations), and thus, regulate the host immune response. In gross terms, cytokines induce inflammation in response to tissue injury, infection, or exposure to toxic chemicals (Ashley and Weil 2012) and attract immune cells to the site of injury or infection. A naive T-lymphocyte makes two types of T-helper cells, Th1 and Th 2 cells. The Th1 cells facilitate the cell-mediated immune response, whereas Th2 cells facilitate humoral immune response (Mosmann and Coffman 1989). Subsequently, Th17 was identified as another inducer of inflammation (Patel and Kuchroo 2015). Unlike helper T-cells, T-regulatory cells, despite having a CD4 co-receptor on their surface, suppress the inflammatory response. Therefore, in response to mild or nonlethal infections, the T-reg cells will take over the maintenance of immune homeostasis (Fig. 2). However, excessive cytokine production can lead to tissue damage and sepsis. For this reason, cytokine targeting has emerged as an alternate mechanism to intervene in the inflammation (D'Elia et al. 2013).

Between the cytokines, the pro-inflammatory cytokines (IL-1 $\alpha$, IL-1 $\beta$, IL-2, IL-6, IL-8, IL-11, IL-12, IL-17, IL-18, Il-20, IL-23, IL-33, TNF- $\alpha$, IFN- $\gamma$, BASFF, LIF, OSM, TGF- $\beta$, and GM-CSF, and chemokine, MCP-1) produced from Th1 cells and macrophages aggravate the inflammation, whereas the anti-inflammatory cytokines (IL-4, IL-6, IL-10, IL-11, IL-13, EGF, and TNF- $\beta$ ) produced from Th2 cells decreases the inflammation (Dinarello 2007) (Fig. 3). It is interesting to see cytokines such as IL-6 are exhibiting overlapping functions. Th1 cells respond to microorganisms and cancer (Goldszmid et al. 2014), whereas Th2 cells respond to parasite infections (Bourreau et al. 2003). Chemokines are small cytokines produced by normal cells and majorly from the immune cells. Due to their involvement in chemotaxis and cell movement, they function as signalling proteins. Similar to cytokines, chemokines also exhibit pro- and anti-inflammatory responses (Sharma 2015). They are classified based on the number of sulfhydryl groups $(\mathrm{S}-\mathrm{S})$ in them, and they are majorly categorised as CXC (CXCL-1, CXCL-2, CXCL-8, CXCL-10, CXCL-12, CXCL-14, CXCL-17) and CC (CCL1, CCL2, CCL3, CCL4, CCL-5) types (Palomino and Marti 2015; Turner et al. 2014) (Fig. 4). Chemokines coordinate with cytokines in an orchestrated manner to regulate the inflammatory responses (Turner et al. 2014; Karin and Wildbaum 2015).

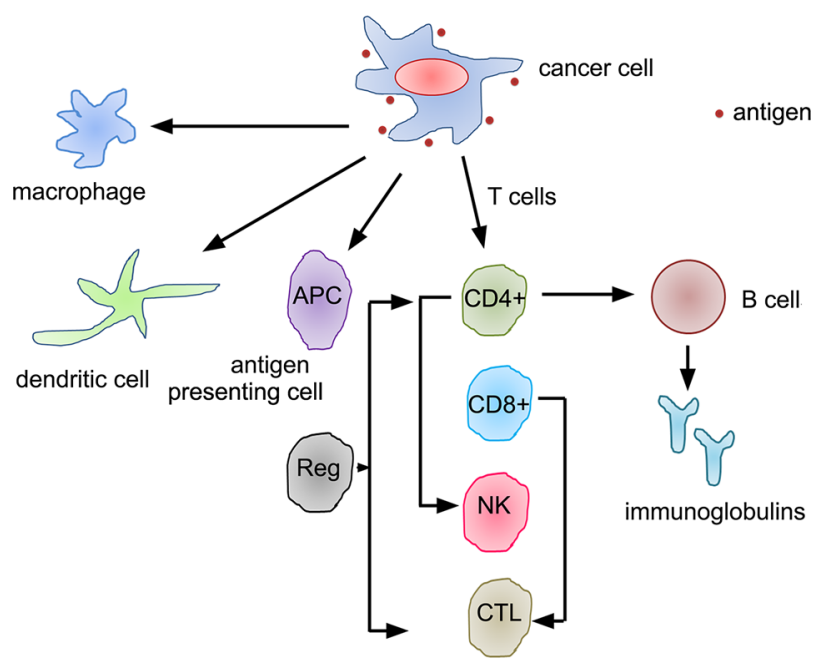

Fig. 2 The immune signalling and the crosstalk between $\mathrm{T}$ - and B-cell responses. The immune system responds to cancer cells and activates the specific and non-specific immune signalling. While surface tumour antigens facilitate immune reaction, the cytokines released by the tumour cells attract antigen-presenting cells, macrophages, dendritic cells, and T- and B-lymphocytes towards infection sites. While T-cells can trigger antibody-dependent and antibodyindependent immune responses through CD4+and CD8+T-cells, respectively, B-cells are involved in antibody-dependent immune reactions: T-cells T-lymphocytes, B-cells B-lymphocytes, APC antigen-presenting cell, Reg regulatory T-cells, $C D 4+\mathrm{CD} 4$ positive T-cells, $C D 8+$ CD8 positive T-cells, $N K$ natural killer cells, $C T L$ cytotoxic T-lymphocytes

The cytokine response can be inhibited by selective cytokine inhibitors, antibodies against specific cytokines, cytokine receptor antagonists for both membrane and soluble receptors, inhibitors/modulators of cytokine signal transduction, and their transcriptional regulation. Since a cascade of events occurs during the cytokine storm (uncontrolled release of cytokines), the direct cytokine inhibitors, receptor inhibitors, and signal transduction inhibitors have been used to interfere with the cytokine storm. We describe a few commonly used drugs, inhibitors, and drug candidates against cytokine storm in the following sections.

\section{Viruses and cytokine storm}

Inflammation is a host response to untoward cellular insults and is grossly considered as a host defence mechanism. When an inflammatory response (i.e. cytokine release) occurs in a regulated manner, it is called adaptive. If it happens in an uncontrolled way, it leads to a pathological outcome (Varela et al. 2018). Therefore, the location and variation of cytokine response also can decide the consequences of infection (Noah et al. 2012). Many viral infections can elicit cytokine responses (Tisoncik et al. 2012). Cytokine 


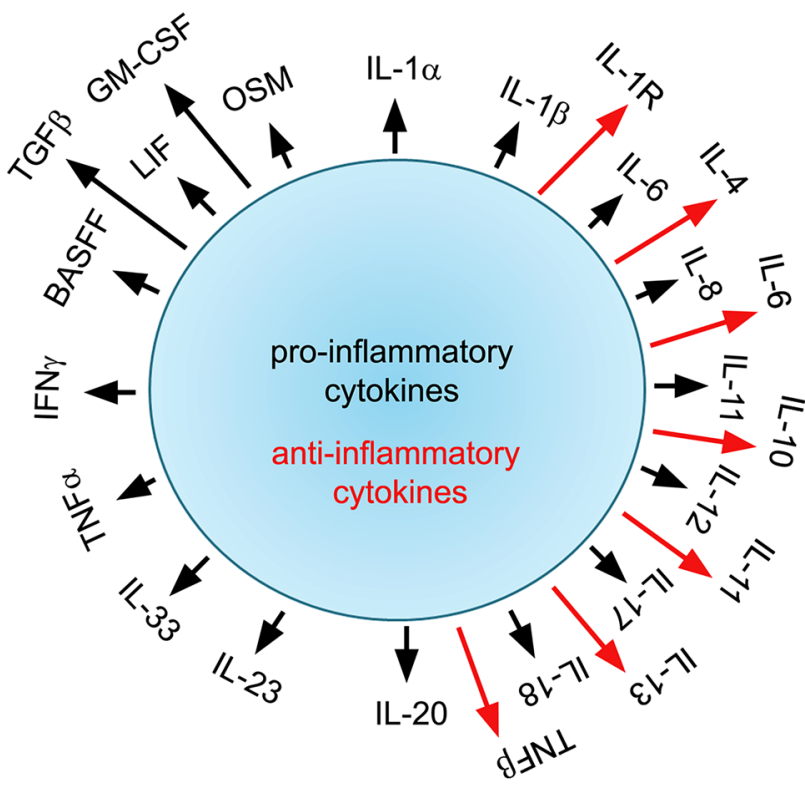

Fig. 3 Pro- and anti-inflammatory cytokines as the name suggests trigger pro- and anti-inflammatory response. The pro-inflammatory cytokines facilitate the inflammatory response leading to pain and tissue damage, whereas the anti-inflammatory cytokines counteract the inflammatory reactions. The inflammatory cytokines function either alone or in a coordinated manner. The chronic inflammatory cytokine response facilitates host defence against infection. However, the acute inflammatory response or cytokine storm can cause excessive tissue damage and organ failure. The black colour arrows indicate pro-inflammatory cytokines, whereas red colour arrows indicate anti-inflammatory cytokines. Note some dual roles of cytokines. Also, note this is not a complete list of cytokines

storm is nothing but the overproduction of pro-inflammatory cytokines triggering the hyper-inflammatory response. If the cytokine release is site-specific, it is called local inflammation (i.e. infected cells/tissues and wound/injured site). Unsolicited cytokine production invites immune cells to non-specific sites, thus damaging the unaffected cells/tissues/organs. The cytokines induced in incidences like influenza are considered non-lethal. However, overproduction of these cytokines can also cause severe neuronal damage (Yokota 2003; Ichiyama et al. 2003; Beigel et al. 2005).

\section{Cancer and cytokine storm}

Cancer emerges from the loss of fine-tuning between the tumour suppressor and oncogenes and epigenetic alterations (Zhu et al. 2015; Kanwal et al. 2015; Blackadar 2016). The host immune system usually takes care of tumour development by inducing inflammatory responses that exhibit antitumour activity. In gross terms, the outcome of cancer pathogenesis depends on host immunity (Gonzalez et al. 2018). Further, cancer immunity shown at various developmental

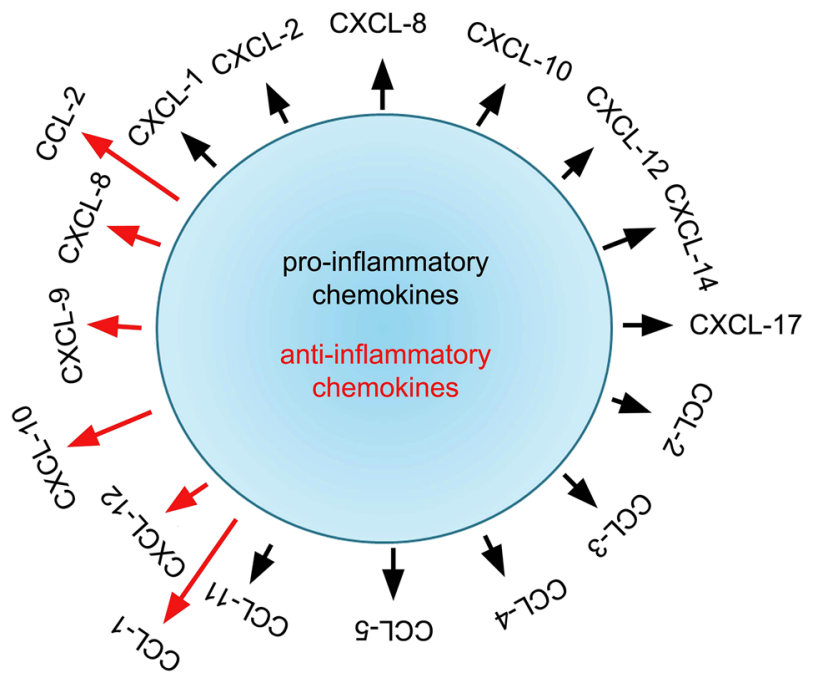

Fig. 4 Pro- and anti-inflammatory chemokines as the name suggests trigger pro- and anti-inflammatory response. Chemokines play a crucial role in attracting immune cells to the site of infection. The large number of chemokines and their receptors suggest a high degree of specificity. The pro-inflammatory chemokines facilitate the inflammatory response leading to tissue damage, whereas the anti-inflammatory chemokines inhibit the same. Chemokines promote the chemoattraction of effector immune cells such as leukocytes, neutrophils, monocytes, etc. The black colour arrows indicate pro-inflammatory chemokines, whereas red colour arrows indicate anti-inflammatory chemokines. Note some dual roles of chemokines. Also, note this is not a complete list of chemokines

stages contributes to the fundamental cancer phenotypes (Hanahan and Weinberg 2011). Additionally, cancer immunity is associated with the compromised immune checkpoints such as programmed cell death protein 1 (PD-1) or its ligand (PD-L1) (Pio et al. 2019). Since cancer inflammation favours carcinogenesis (Balkwill and Mantovani 2001; Germano et al. 2008; Chen and Mellman 2013; Müzes and Sipos 2015), the stage-specific alterations in inflammatory cytokines appear to contribute to immune evasion (Gonzalez et al. 2018). Cytokines promote tumour growth and spread in an autocrine or paracrine manner. The autocrine mechanisms trigger proliferative potential, whereas the paracrine mechanisms initiate cellular transformation and tumour spread (Mantovani 1994; Negus and Balkwill 1996). Various cytokines involved in cancer progression are well-reviewed by Dunlop and Campbell (2000).

\section{Cytokine storm: cancer versus viral infection}

Several factors, cytokines, interleukins, chemokines, interferons, tumour necrosis factor, and growth factors play a central role in directing the immune cells to reach the target cells (Oppenheim and Fujiwara 1996). However, tumour cells can exhibit low immunogenicity for two reasons, (1) 
they arise from the normal cells of the host, and (2) they exist in a heterogeneous population (Vinay et al. 2015). Therefore, it is necessary to trigger a specific or selective antitumour immune response in the host (Chulpanova et al. 2020). Tumour cells can manipulate the host immunity by overexpression of checkpoint molecules such as PD1 and FasL, cytokine suppressors IL-10 and IL-17, and manipulators of tumour microenvironment TGF $\beta$ and IL-4, modulation of ligands that bind to MHC molecules, etc. (Pandya et al. 2016). Since cancer emergence is an adaptive response, the chronic inflammation usually observed in tumour cells favours them from targeting self (Singh et al. 2017). Therefore, triggering a specific host immune response is suggested (Blankenstein et al. 2012; Li 2018). The cytokines such as IL-2, IL-12, and TNF $\alpha$ are directly used in anticancer therapies to trigger host immunity (van Horssen et al. 2006; Tugues et al. 2014; Jiang et al. 2016). The use of recombinant oncolytic virus treatments that infects cancer cells and promote cell killing was found to be very promising (Andreansky et al. 1998; Fu et al. 2019). In agreement that viral infections induce an inflammatory response, the engineered oncolytic virus with tumour-specific antigens may also elicit an efficient antitumour response. The limitations imposed by this strategy include tumour heterogeneity, physical barriers in solid tumours, and the impact of the tumour microenvironment (Gulley et al. 2017; Zheng et al. 2019).

\section{SARS-CoV-2 and cytokine storm}

The SARS-CoV-2, the severe acute respiratory syndrome coronavirus infection, has been shown to elicit cytokine response on post-viral infection to drive immune cells such as macrophages, NK cells, and dendritic cells to the site of infection, i.e. lungs (Chen et al. 2010). Subsequently, the SARS-CoV-2 that causes coronavirus disease (COVID19 ) is also shown to induce a cytokine storm (Song et al. 2020; Ye et al. 2020). The spike protein, S, binds to the angiotensin-converting enzyme 2 (ACE2), which is abundantly expressed in the kidney, heart, lung, and intestine and induces an unwarranted immune response (Kuba et al. 2005; Lan et al. 2020). A few ACE inhibitors with clinical implications are being reviewed by Sweitzer (2003) and suggested to be useful against COVID-19 patients, including patients with hypertension (Hippisley-Cox et al. 2020; Meng et al. 2020). However, it was also indicated that additional data are required to make firm conclusions, and available data should be used with caution for interpretations (Liu et al. 2020a).

Under defective or low immunity, the immune system responds to infection and triggers cytokine production. It could be the reason why cancer patients with low immunity are at risk for COVID-19 (Liang et al. 2020; Lee et al. 2020). The risk assessment was performed based on invasive ventilation, ICU admission, clinical indication, and death between normal versus cancer patients with COVID-19 infection. Although these studies are pertinent to a subpopulation from east Asia (Liang et al. 2020; Liu et al. 2020b), a cohort study that included the USA, Canada, and Spain also suggests that cancer patients are in the high-risk group (Kuderer et al. 2020). However, due to a small sample size or limited demographic data analyses, these correlations did not provide conclusive information (Desai et al. 2020; Wang and Zhang 2020) but provided a possibility that such correlation may be possible.

Since there is an overlap in the potential molecular mechanisms between the inflammatory responses induced by virus infections and autoimmune disorders (Smatti et al. 2019), SARS-CoV-2 disease can also exhibit a similar response. In agreement with this, COVID-19 patients are shown to express autoantibodies to the immunomodulatory molecules that include cytokines (Wang et al. 2020a), potentially leading to autoimmune disorders (Galeotti and Bayry 2020; Mateu-Salat et al. 2020).

Among different cancers, the haematological, lung, and breast cancer patients were reported to be at high risk (Rugge et al. 2020). Interestingly, cancer progression is linked to cytokine-mediated cellular transformation of bystander cells (Dranoff 2004). Nevertheless, the cytokines are being suggested for cancer treatment, indicating that they need to be used in a context-based manner and with precaution (Vilcek and Feldmann 2004; Kim-Schulze et al. 2007; Lee and Margolin 2011; Conlon et al. 2019). Since proinflammatory cytokines negatively influence host immunity against infection, a natural cytokine treatment has both advantages and disadvantages (Rider et al. 2016). The SARS-CoV-2 infection in cancer patients exhibits an aggravated cytokine response, contributing to increased mortality rates (Turnquist et al. 2020; Khalid et al. 2020; Weatherford et al. 2020). Hence, interfering with the cytokine storm appears to be a prerogative response against virus-infected cancer patients.

\section{Inflammation and pain}

Inflammation is a dynamic response to tissue injury to clear the damaged tissue or infected cells. Stress is inevitable, and all living beings experience and respond to stress. Pain is a distressing sensation caused by tissue injury, where inflammation triggers pain (Watkins et al. 2003; Zhang and An 2007). Since inflammatory cytokines can trigger tissue damage, they will have a more significant impact in triggering the host's pain response at different locations (Navarra et al. 1991; Lyson et al. 1991; Leonard 2015; Muley et al. 2016). The SARS-CoV-2 infection also can cause pain in distant locations than the primary infected sites (Acharya et al. 
2020; Smyk et al. 2020). Various receptors, such as opioids, vanilloid, capsaicin, are implicated in pain response (Tominaga and Julius 2000; Caterina and Julius 2001; Pathan and Williams 2012). Interestingly, the respiratory viruses can also induce intracellular pain receptors and persuade pain in response to tissue damage (Omar et al. 2017). Since SARSCoV-2 infection is also a respiratory infection, the involvement of pain receptors during virus infections can also be considered for treating pain.

The cyclooxygenases (COX enzymes) are implicated in pain response. Between the two major COX enzymes, COX-1 functions constitutively to maintain tissue homeostasis, whereas COX-2 is involved in inflammation and pain (Williams et al. 1999; Deeb et al. 2008). COX-2 contributes to cancer progression by inducing the pro-inflammatory cytokines, however, suppressing the host immunity. It could be why COX-2 has become a pharmacological target against cancer (Liu et al. 2015; Hashemi Goradel et al. 2019; Table 1). Like in cancer inflammation, SARS-CoV-2 infection also triggers the transcription of COX-2, indicating its involvement in the disease outcome (Liu et al. 2007; Das 2020). The lipoxygenases are lipid mediators and are

Table 1 A few known NSAIDS as COX inhibitors

\begin{tabular}{|c|c|c|}
\hline Drug candidate & Physiological effects & Inhibits \\
\hline Aspirin & $\begin{array}{l}\text { Anti-inflammatory, analgesic, and } \\
\text { antipyretic }\end{array}$ & $\mathrm{COX}-1$ \\
\hline Celecoxib & Anti-inflammatory & $\mathrm{COX}-2$ \\
\hline Diclofenac & Anti-inflammatory and analgesic & $\mathrm{COX}-1 / 2$ \\
\hline Etodolac & Anti-inflammatory & $\mathrm{COX}-2$ \\
\hline Etorocoxib & $\begin{array}{l}\text { Anti-inflammatory, analgesic, and } \\
\text { antipyretic }\end{array}$ & COX-2 \\
\hline Fenoprofen & $\begin{array}{l}\text { Anti-inflammatory, analgesic, and } \\
\text { antipyretic }\end{array}$ & $\mathrm{COX}-1 / 2$ \\
\hline Flurbiprofen & $\begin{array}{l}\text { Anti-inflammatory, anti-miotic, and } \\
\text { antipyretic }\end{array}$ & $\mathrm{COX}-1 / 2$ \\
\hline Ibuprofen & $\begin{array}{l}\text { Anti-inflammatory, analgesic, and } \\
\text { antipyretic }\end{array}$ & $\mathrm{COX}-1 / 2$ \\
\hline Indomethacin & $\begin{array}{l}\text { Anti-inflammatory, analgesic, and } \\
\text { antipyretic }\end{array}$ & $\mathrm{COX}-1 / 2$ \\
\hline Ketoprofen & $\begin{array}{l}\text { Anti-inflammatory, analgesic, and } \\
\text { antipyretic }\end{array}$ & $\mathrm{COX}-1 / 2$ \\
\hline Ketorolac & Anti-inflammatory and analgesic & $\mathrm{COX}-1 / 2$ \\
\hline Meclofenamate & Anti-inflammatory and analgesic & $\mathrm{COX}-1 / 2$ \\
\hline Mefanamic acid & Anti-inflammatory and analgesic & $\mathrm{COX}-1 / 2$ \\
\hline Meloxicam & Anti-inflammatory and analgesic & $\mathrm{COX}-2$ \\
\hline Nabumetone & Anti-inflammatory & $\mathrm{COX}-1 / 2$ \\
\hline Naproxen & $\begin{array}{l}\text { Anti-inflammatory, analgesic, and } \\
\text { antipyretic }\end{array}$ & $\mathrm{COX}-1 / 2$ \\
\hline Oxaprozin & Anti-inflammatory and analgesic & $\mathrm{COX}-1 / 2$ \\
\hline Piroxicam & Anti-inflammatory & $\mathrm{COX}-1 / 2$ \\
\hline Sulindac & Anti-inflammatory & $\mathrm{COX}-1 / 2$ \\
\hline Tolmetin & Anti-inflammatory and analgesic & $\mathrm{COX}-1 / 2$ \\
\hline
\end{tabular}

involved in producing the leukotrienes, which act as chemoattractants for immune cells (Peters-Golden and Henderson 2007). In the case of SARS-CoV-2 infection, leukotrienes are not paid attention to (Funk and Ardakani 2020). Since leukotriene inhibitors are used in anti-cancer treatments (Steele et al. 1999; Werz and Steinhillber 2006), they are also suggested for COVID-19 patients (Citron et al. 2020; Funk and Ardakani 2020). However, it has been recommended that ACE inhibitors in combination with NSAIDs increase the risk of kidney injury, yet, sufficient scientific evidence has not been established for this (Zolk et al. 2020).

\section{Inflammatory signal transduction pathways}

The inflammatory signal transduction involves pattern recognition receptors (PRRs) both on the cell surface and in the cytoplasm. The primary role of PRRs is to respond to pathogen-associated molecular patterns (PAMPs) or damageassociated molecular patterns (DAMPs); where the former one is related to infection, the latter one emerges from the host response (Bianchi 2007; Newton and Dixit 2012). Since the influenza virus shares homology with SARS-CoV-2, there may be an overlap of inflammatory signal transduction pathways. Similar to spike protein, PAMPs also recognise ACE-2 receptors and activate toll-like receptors (TLRs). These TLRs spanning the plasma membrane have cytosolic adaptors, which activate transcription factors such as NF-kB, AP1, CREB, IRF, etc. It is also interesting to note that some of the mitogen-activated protein kinase (MAPK) members are also involved in such signalling events. Since mitogen signal transduction is vital for host cell survival, MAPK inhibitors cannot be used for infection-induced inflammation (Catanzaro et al. 2020). However, the MyD88, which is upstream of MAPK, can act as an adaptor for TLR; thus, it appears to be one such target (Kawasaki and Kawai 2014). It could be why the signal transduction pathways leading to cytokine production have become attractive targets for antiinflammatory therapeutics. A review by Gao et al. (2017) summarises some of the TLR inhibitors in the application front for treatment.

Among several cytokine receptors associated with disease pathology, type I and type II superfamily are linked with Janus Kinases (JAKs). Since JAK1/2 responds to multiple cytokine receptors, targeting JAKs with conventional kinase inhibitors is proposed to interfere with the inflammatory responses (Schwartz et al. 2017). The signal activator and transducer (STAT) transcriptional factors are activated in response to JAK signalling. Therefore, the JAKSTAT signalling pathway has become an attractive target for interfering with inflammation. Interestingly, the STAT protein activation serves a dual role: (1) to trigger inflammation in response to cytokine binding to its receptor and 
(2) to suppress cytokine response. For this reason, only JAK inhibitors are used against inflammation (Yoshimura et al. 2003) (Fig. 5). Hence, several JAK inhibitors such as ruxolitinib, baricitinib, fedratinib, olacitinib, tofacitinib, solcitinib, filogotinib, upadacitinib, decernotinib, PF-06651600, etc. can be examined against COVID-19 (O'Shea et al. 2013; Schwartz et al. 2017; Seif et al. 2020; Table 2). Towards this, NIH News Release indicated a randomised, controlled clinical trial of the JAK inhibitor baricinitib for COVID-19 treatment. Similarly, the JAK inhibitors such as ruxolitinib combined with eculizumab are effective against SARSCoV-2 (Giudice et al. 2020).

The c-jun N-terminal kinase (JNK) stress signalling pathway is also implicated in cancer progression. However, this kinase exhibits a dual role both as an oncogene and tumour suppressor (Tournier 2013). The JNK pathway modulates cell death pathways in infectious bronchitis virus (IBV) virus infection suggests that it contributes to disease pathogenicity (Fung and Liu 2017). Interestingly, it has been shown that the JNK pathway contributes to SARS-CoV-2 pathogenesis (Mizutani 2009; Mizutani et al. 2005; Singh et al. 2020). An updated list of selective JNK inhibitors suggests that they can be used against infection and stress-activated stress signalling like cancer (Wu et al. 2020a). No significant findings were made linking JNK pathways with SARS-CoV-2

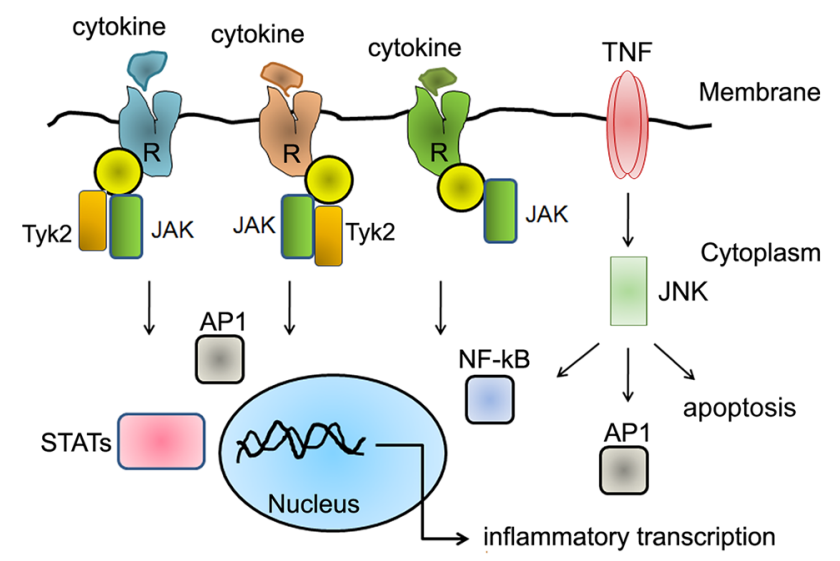

Fig. 5 Common signal transduction pathways triggered by cytokines. Cytokines, after binding to their respective receptors (type I cytokine receptors, type II cytokine receptors, TNF receptors, G-coupled receptors, TGF- $\beta$ receptors, Immunoglobulin superfamily of receptors) activate JAK or Tyk2, which in turn can trigger the transcriptional activation of several inflammatory transcription factors such as STAT, NFkB, AP-1, etc. These transcription factors contribute to the inflammatory response, whereas chemokine receptors belong to seven-transmembrane families and elicit a similar intracellular response like cytokines; JAK Janus Kinase, $A P-1$ activator protein-1, $N F-k B$ nuclear factor kappa-light-chain-enhancer of activated B cells, STATs signal transducer and activator of transcription factors, $I R F$ interferon regulatory transcription factor, $J N K$ c-jun $\mathrm{N}$-terminal Kinase, $T y k 2$ non-receptor tyrosine kinase 2, $T N F$ tumour necrosis factor
Table 2 A few known kinase inhibitors

\begin{tabular}{ll}
\hline Drug candidate & Molecular target \\
\hline Baricitinib & JAK1/2/3 \\
BMS-986165 & Tyk2 \\
Decernotinib & JAK-3 \\
Delgocitinib & pan inhibitor of JAKs \\
Fedratinib & JAK-2 \\
Filgotinib & JAK-1 \\
Itacitinib & JAK-1 \\
NDI-031232 & Tyk2 \\
NDI-031407 & Tyk2 \\
Olacitinib & JAK1/2/3 \\
Peficitinib & JAK-1/2/3 \\
PF-06651600 & JAK-3 \\
PF-06826647 & Tyk2/JAK-1/2 \\
Ruxolitinib & JAK1/2 \\
SAR-20347 & Tyk2/JAK-1/2/3 \\
Solcitinib & JAK-1 \\
Tofacitinib & JAK1/3 \\
Upadacitinib & JAK-1 \\
\hline
\end{tabular}

infection, which may need to be examined. Like JNK, nonreceptor tyrosine kinase2 (Tyk2) is implicated in cancer progression (Wöss et al. 2019; Fig. 5). Tyk2 has already been identified as a target for viral pneumonia (Berg et al. 2017). Therefore, the available Tyk2 inhibitors (Table 2) can be examined against SARS-CoV-2 induced inflammatory signal transduction.

\section{The overlapping functions of cytokine storm in cancer and SARS-CoV-2 infections}

Inflammation has been identified as a facilitator of tumour progression (Philip et al. 2004; Lu et al. 2006). However, in the case of SAR-CoV-2 infections, although the clinical features correlate with influenza (Liu et al. 2016), the serum levels of IL-2 and IL- 6 were suggested to act as prognostic markers (Chen et al. 2010). Subsequent studies have indicated how cytokine storm leads to pathological outcome (Zhou et al. 2020a). Although there are suggested treatment regimens to interfere with cytokine storm (Schulert and Grom 2015), inducing the anti-inflammatory responses by triggering a specific transcriptional response was found to be effective (Brun-Buisson et al. 2011). Subsequently, several drugs and inhibitors are effective against cytokine storm, including statins, antioxidants, anti-immunoglobulin injections, COX-2 inhibitors, and anti-TNF agents, etc. (Holdsworth and Gan 2015; Liu et al. 2016; Wang et al. 2020b; Liu and Ying 2020). 
After the SARS-CoV-2 infection, during COVID-19 disease, the first stage shows high viral load and fewer symptoms on 1-2 weeks of post-viral infection (Zhou et al. 2020b). In contrast, the second stage shows increased cytokine storm and organ failure and may last for weeks (Guo et al. 2020). The primary target of SARS-CoV-2 is the ACE-2 receptors in the lung epithelium (Kuba et al. 2005; Lan et al. 2020). Pro-inflammatory cytokine involvement and their effective inhibition using tocilizumab, myoinositol, azithromycin, chloroquine, certolizumab, etc. were suggested (Costela-Ruiz et al. 2020; Cortegiani et al. 2020). The cytokine response, therefore, also acts as an indicator of viral load and disease severity. Since there are no universal cytokine response signalling patterns that work in a disease or infection-specific manner, drugs that inhibit inflammatory cytokines in cancer and other conditions may work against COVID-19 (Luo et al. 2020). Based on the literature survey, it is possible to repurpose anticancer and anti-inflammatory drugs to lower the cytokine overload in COVID-19 (Fig. 6).

Anticancer drugs can induce immunosuppression; therefore, loss of tumour growth at the primary location does not always signify decreased tumour load in response to chemotherapy. A decrease in tumour growth at the primary location could also signify enhanced or acquired metastatic potential of tumour cells (Penn 1975). Since conventional chemotherapy fails to intervene with the unwarranted cytokine response, combined immunotherapy with chemotherapy has emerged as a novel strategy

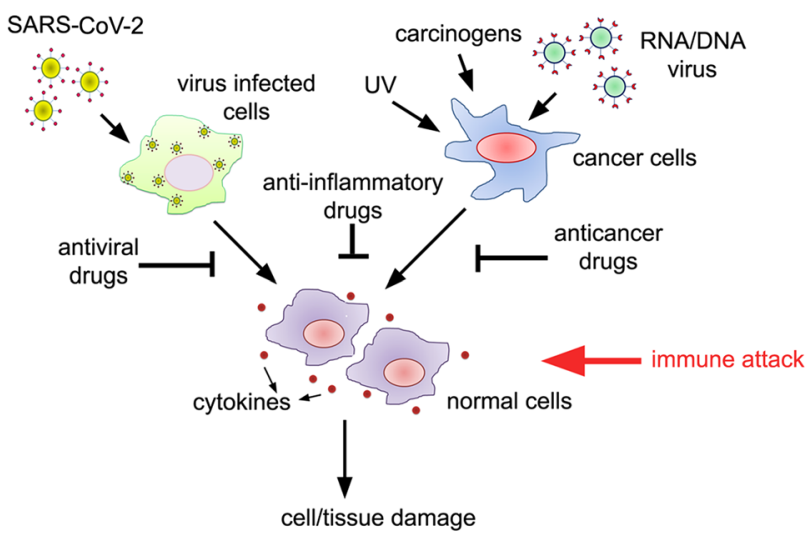

Fig. 6 The co-similarity between SARS-CoV-2 infected cells and cancer cells in inducing the cytokine response. Both virus-infected cells and cancer cells release the cytokines, influencing the bystander cells or normal cells to undergo neoplastic transformation or tissue damage. Therefore, targeting the cytokine storm using antiviral, antiinflammatory, or anticancer drugs can lower the cytokine overloadand thus may protect bystander/normal cells. The cytokine storm otherwise induces unwarranted cell killing leading to excessive tissue damage leading to organ failure. Since cancer cells can bypass immune attack, they may survive the cytokine storm and induce transformation in normal cells to become cancerous. In contrast, cytokine storms caused by SARS-CoV-2 can lead to tissue damage to combat cancer (Vanneman and Dranoff 2012). Among the modulators of cancer immunity, the checkpoint inhibitors, PD-1 and its ligand PD-L1, and CTLA- 4 can be targeted by chemical entities or monoclonal antibodies (Rotte 2019). Similarly, chimeric antigen receptor (CAR)-T cell therapy and oncolytic virus infections are also useful (Guedan and Alemany 2018). There is a long list of antiinflammatory drugs used against cancers, which may not directly elicit anticancer properties but are efficient against the cytokine storm and sensitise tumour cells to conventional chemotherapeutic drugs (Rayburn et al. 2009; Zappavigna et al. 2020).

Since anticancer drugs or drugs used against cancer inflammation can also intervene with the cytokine storm induced by the SARS-CoV-2 virus, the scope of using these drugs against COVID19 is encouraging (Saini et al. 2020; Ciliberto et al. 2020; $\mathrm{Hu}$ et al. 2020). Among the three significant steps considered to target any viral infections, preventing virus entry into the host, interfering with the virus replication in the host, and interfering with the unwarranted immune response appeared to be critical (Stebbing et al. 2020; Cheng et al. 2020). Further, the classical antiviral drugs such as remdesivir can interfere with RNA-dependant RNA polymerase functions (Beigel et al. 2020) may not address the concerns raised by the cytokine storm. Therefore, repurposing the drugs used against cancer inflammation can be examined against SARS-CoV-2 infection as a complementary therapy.

\section{Potential inhibitors of cytokine storm in the context of SARS-CoV-2}

\section{BCG vaccine}

$\mathrm{BCG}$ is a freeze preparation containing live bacteria derived from an attenuated strain of mycobacterium bovis known as Bacillus of Calmette and Guerin and used against tuberculosis. BCG is ineffective against HIV infections wherein there is an extensive immunosuppression reported (Dheda et al. 2017). Similar to SARS-CoV-2, Mycobacterium infection also triggers innate immune responses (Cooper and Khader 2008). Therefore, the BCG vaccine is thought to sensitise the host system against COVID-19 (Escobar et al. 2019; Arlehamn et al. 2020; O'Neill and Netea 2020). Although BCG was speculated to intervene SARS-CoV-2 related inflammatory response, sufficient scientifically approved data could not be obtained to strengthen this. Further, no strong correlation could be drawn from the available epidemiological data sets between BCG vaccination and SARS-CoV-2 infection. 


\section{Bordetella Pertussis}

Bordetella Pertussis is a gram-negative bacterium whose infection causes whooping cough and severe respiratory malfunctions leading to bronchopneumonia and encephalopathy. The severity and the outcome of the disease depend on the host's innate immunity. Heat killed bacterium is used as a vaccine to reduce the cytokine storm ( $\mathrm{Li}$ et al. 2010) and could be the reason why it was suggested for COVID19 (Alkholy et al. 2020). The World Health Organization (WHO), in a recent report on Mythblasters, has indicated that vaccines against pneumonia will not protect individuals from COVID-19 since scientific evidence to support such claims is lacking (Convertino et al. 2020).

\section{Sepsis}

Sepsis is a systematic response to organ dysfunction induced by infection. Overproduction of cytokines results in sepsis (Rittirsch et al. 2008; Boomer et al. 2011). Sepsis-induced organ dysfunction in COVID-19 patients has been reported (Lin 2020). Blood being the primary carrier for cytokine distribution to various tissues in the body, hemoperfusion has been suggested for severe sepsis/lung injury as reviewed (Chaudhry et al. 2013; Schädler et al. 2013). However, neither scientific nor clinical data relevant to hemoperfusion and SARS-CoV-2 infections are available (Li et al. 2020a). Interestingly, the use of plasma from the COVID-19 recovered patients is effective against SARS-CoV-2 infection but was broadly thought to come from the antibody-mediated virus inhibition (Yiğenoğlu et al. 2020; Sedokani and Feizollahzadeh 2020; Farhat et al. 2020). However, more conclusive data are needed to confirm these findings.

\section{Azathioprine}

Azathioprine acts as an immune modulator to suppress the host response (Fuss et al. 1999; Yeo et al. 2019). Therefore, it is grossly used to prevent graft rejection during organ transplantation and inhibits inflammation during rheumatoid arthritis (Rodrígues-Perálvarez et al. 2014; Suarez-Almazor et al. 2000). Due to its immunosuppressant activity, it is suggested to be used against the cytokine storm in respiratory distress, however, in combination treatments (Vaz et al. 2011; Shorr et al. 2003; Wu et al. 2020b). Azithromycin is now shown to reduce the viral load in early SARS-CoV-2 infection either alone or in combination with chloroquine (Rajaiah et al. 2020; Lagier et al. 2020).

\section{Methotrexate}

Methotrexate was initially used to slow down cancer cell growth and subsequently showed to exhibit immune-suppressant activity. Methotrexate is effective against COVID-19 induced cytokine production alone or with JAK1/2 inhibitors (Khan and Durairaj 2020). Since it works against arthritis to reduce inflammation, it is being suggested for COVD-19 (Frohman et al. 2020; Rajaiah et al. 2020).

\section{Glucocorticoids}

Glucocorticoids are produced by the adrenal glands and are known to suppress the immune responses by inhibiting inflammation and activating pro-inflammatory responses (Fantuzzi and Ghezzi 1993; Schwiebert et al. 1996). Since glucocorticoid receptor stabilisation and ligand-receptor interactions are regulated by the molecular chaperone Hsp90, interfering with the chaperoning functions of Hsp90 is also implicated in interfering with the cytokine inhibitory response (Morishima et al. 2018). Considering their anti-inflammatory response, treating COVID-19 patients with corticosteroid drugs was strongly suggested (Cook et al. 2015; RECOVERY Collaborative Group et al. 2020; Johnson and Vinetz 2020). The corticosteroids are widely used against SARS and MERS, and for COVID-19 treatment, they were already used at the clinic and shown to have beneficial outcomes (Zha et al. 2019).

\section{Monoclonal antibodies}

There are now a few approved vaccine or vaccine candidates against COVID-19 that include antibodies. The available monoclonal antibodies aim to spike glycoproteins on SARS-CoV-2 and interfere with the virus's host cell entry (Marovich et al. 2020; Shanmugaraj et al. 2020; Sewell et al. 2020). However, it is suggested that antibodies against the conformationally altered T-lymphocytes and their receptors can more efficiently decrease the circulating lymphocytes and the cytokine storm (Hu et al. 2020). Therefore, research towards developing specific monoclonal antibodies against cytokines and their respective receptors may be effective against the cytokine storm.

\section{C-reactive protein}

The C-reactive protein (CRP) levels in the blood acts as an indicator for inflammation. Since increased CRP appears to decrease cytokine levels, they are implicated in anti-cytokine response (Mallya et al. 1982; Pradhan et al. 2001) and suggested for the risk assessment during COVID-19 (Sahu et al. 2020; Wang et al. 2020c; Yang et al. 2020b). Interestingly, few anti-inflammatory drugs that are shown to reduce CRP levels (Prasad 2006; Zhang et al. 2016) are associated with COVID-19 (Zhang et al. 2020a). Ulinastatin has effectively reduced serum CRP levels and systemic inflammation 
(Zhang et al. 2016). Therefore, this drug is suggested for COVID-19 as an adjuvant treatment (Dixit et al. 2020).

\section{Anti pain/analgesic drugs}

Opioid agonists such as tramadol, codeine, morphine, etc. are considered the most potent pain killers. Non-opioid agonists such as paracetamol, ibuprofen, aspirin, etc. are used against chronic pain. The opioid pain killers interfere with membrane receptors, and the non-opioid pain killers interfere with metabolic pathways (Graham and Scott 2005; Orlando et al. 2015). Both opioid and non-opioid drugs have been suggested for COVID-19 patients (Rinott et al. 2020; Shanthanna et al. 2020) for pain management (El-Tallawy et al. 2020). However, opioid overdose leads to compromised immune functions. It could be the reason why individuals with opioid addiction are considered to be at high risk for COVID-19 (Dubey et al. 2020).

\section{Anti-inflammatory drugs: cancer versus COVID-19}

The inflammatory cytokines from cancer cells can promote the neoplastic transformation of bystander cells. Therefore, interfering with inflammatory responses impede cancer spread and progression (Hofseth and Ying 2006; Arias et al. 2007). In addition to chemotherapeutic drugs that can promote cytotoxicity in target cells, hormonal therapy or steroid therapy has emerged as an alternate strategy to treat cancer. The hormonal therapy is effective against hormoneresponsive tumour cells from the breast and endometrium in females and prostate in males. Interestingly, several drugs that interfere with hormone regulatory pathways are known to interfere with inflammatory responses (Sereda and Werth 2006; Leggas et al. 2009). Nonsteroidal anti-inflammatory drugs are being used against cancer to reduce tumour inflammation (Thun et al. 2002; Kim-Schulze et al. 2007). Among commonly used antitumour inflammatory drugs, $\mathrm{COX}$ and LOX inhibitors have gained much attention (Rayburn et al. 2009). However, corticosteroids and commonly used analgesic drugs like aspirin and ibuprofen are also shown to interfere with cancer inflammation. These studies reiterate the potential of repurposing anti-inflammatory and anticancer drugs against COVID-19. Since cancer patients exhibit a two-fold increased risk of COVID infection than healthy individuals, these drugs can be considered.

The intriguing findings indicated that SARS-CoV-2 infection could promote chemoresistance and thus, challenges current anticancer treatments (Vatansev et al. 2020). It suggests the impact of SARS-CoV-2 infection in cancer patients who are on chemotherapy. While the acquired multidrug resistance itself is challenging the cancer treatments (Nikolaou et al. 2018; Vasan et al. 2019; Ward et al. 2020), the virus-induced drug resistance probably leads to adverse consequences, which may hamper recovery from cancer. Further, cancer and SARS-CoV-2 infection can trigger similar or overlapping inflammatory responses. Hence, immune modulation is primarily suggested for the prophylaxis of COVID-19 (Mohamed-Hussein et al. 2020). On the other hand, the anticancer drug ibrutinib, a tyrosine kinase inhibitor, reduces lung inflammation (Florence et al. 2018) and is suggested for COVID-19 (Treon et al. 2020). Several anticancer drugs that can be tested against the complications induced by COVID-19 are already reported (Saini et al. 2020). Several IL-6 inhibitors (Farooqi et al. 2020; Uciechowski and Dempke 2020) and TNF inhibitors (Sedger and McDermott 2014) are suggested to interfere with inflammation induced by COVID-19 (Table 3).

\section{Hydroxychloroquine, azithromycin, and zinc}

The quinone isolated from the cinchona tree is widely used against malarial fever (Ben-Zvi et al. 2012). Subsequently, it is used against various ailments, including antiviral treatments (Al-Bari 2015). Hydroxychloroquine has been shown to enhance anticancer drug effect (Li et al. 2018a; Wang et al. 2019). Interestingly, quinone is effective against chronic inflammation (Li et al. 2018b). The inhibitory effects of hydroxychloroquine against SARS-CoV-2 were promising (Vincent et al. 2005; Yao et al. 2020). Azithromycin, an antibacterial drug, is shown to potentiate the antiviral effects of chloroquine in Plasmodium infection (Sagara et al. 2014) and is subsequently shown to reduce SARS-CoV-2 viral load (Lagier et al. 2020). Chloroquine acts as a zinc ionophore and thus facilitates zinc accumulation (Xue et al. 2014) and potentiates antiviral immune response (Read et al. 2019). It could be the reason why azithromycin and zinc combination with chloroquine has been recommended for the high-risk COVID-19 patients (Derwand and Scholz 2020). Although

Table 3 A few known cytokine inhibitors

\begin{tabular}{ll}
\hline Drug candidate & Target cytokine \\
\hline Adalimumab & TNF \\
Anifrolumab & IFN \\
Certolizumab & TNF \\
Clazakizumab & IL-6 \\
Emapalumab & IFN \\
Etanercept & TNF \\
Golimumab & TNF \\
Infliximab & TNF \\
Olokizumab & IL-6 \\
Sarilumab & IL-6R \\
Sifalimumab & IFN \\
Siltuximab & IL-6 \\
Tocilizumab & IL-6 \\
\hline
\end{tabular}


the initial non-randomised trials with chloroquine and azithromycin were promising (Gautret et al. 2020), combining them with the antiviral drug remdesivir (Risch 2020) and ivermectin (Caly et al. 2020; Sharun et al. 2020) is found to be more effective. A cohort study from the United States of America further strengthens the hypothesis that hydroxychloroquine decreases the mortality associated with the SARS-CoV-2 infection (Gentry et al. 2020). Although some prophylactic role for hydroxychloroquine has been discussed in selected geographical locations (Rathi et al. 2020; Nina and Dash 2020; Mégarbane and Scherrmann 2020; Principi and Esposito 2020), more demographic data sets are needed to conclude.

\section{Examples and mechanisms of action of anti-inflammatory agents against SARS-CoV-2 and cancer}

We discussed how anti-inflammatory and anti-cancer drugs exhibit their potential to work against SARS-CoV-2 infection in earlier sections. In this section, we discuss how these drugs work in cancer patients after SARS-CoV-2 infection. The cancer patients with low immune defence are more prone to SARS-CoV-2 infection. Under these circumstances, any medication used against cancer should also work against viral infection without compromising the immune system. Otherwise, the motive of repurposing anticancer drugs for COVID-19 treatment cannot be achieved (Allegra et al. 2020).

\section{Glucocorticoids: implications and limitations, cancer versus COVID-19}

Unlike sex hormones, progesterone and estrogen, which are also implicated in cancer progression, glucocorticoids act as immunosuppressants and are extensively used for organ transplants (Curtis 2006; Buxant et al. 2010; Pufall 2015; De Lucena and Rangel 2018). The glucocorticoid binding to its receptor can trigger apoptosis in the host cell. Therefore, it is considered an anticancer agent both in haematological and solid tumours (Greenstein et al. 2002; Keith 2008). Glucocorticoids can also exhibit differential responses in different cancer cells (Lin and Wang 2016). Nevertheless, they are considered for treating inflammation (Vandewalle et al. 2018). These studies have indicated that they work against all cancers as anticancer agents by triggering antiinflammatory gene transcription. The chronic use of glucocorticoids can lead to prolonged immunosuppression, which may facilitate novel infections to occur. Therefore, the use of glucocorticoids should be used with caution (Klein et al. 2001).

Glucocorticoids are even suggested for SARS and COVID-19 treatment to reduce inflammation (Cinatl Jr et al.
2005; Xiang et al. 2020). However, since high doses are recommended for acute respiratory infections, prolonged use may lead to opportunistic infections in the background of immune suppression (Klein et al. 2001; Cinatl Jr et al. 2005; Lossignol 2016; Yang et al. 2020a). Since cancer patients are in the high-risk group for COVID-19, addressing SARS-CoV-2 induced inflammation alone with high doses of glucocorticoids can lower host immunity and thus, can aggravate both cancer and virus spread and can invite other infections to occur in cancer patients (Slimano et al. 2020; Hanna et al. 2020; Russell et al. 2020; Table 4). Inducing anti-inflammatory response using moderate doses of glucocorticoids, therefore, appeared to decrease COVID-19 associated mortality.

\section{COVID-19 impact on opportunistic diseases in S. Asia and Sub-Saharan Africa}

After identifying novel coronavirus pneumonia as coronavirus disease, COVID-19 (Jiang et al. 2020), it was found that comorbidities associated with the virus infection may have a more significant impact on the disease outcome (Wang et al. 2020d). Therefore, it was suggested that a thorough evaluation is necessary to understand the actual cause of mortality. While the COVID-19 susceptibility is ascribed to elderly individuals, several factors such as gender, nutrition, and natural immunity need to be considered for appropriate assessment of the disease susceptibility and pathological outcome. The high-calorie diet contributing to obesity and type 2 diabetes is regarded as one of the risk factors for the COVID-19 associated mortality (Butler and Barrientos 2020). Targeting ACE2 receptors that contribute to SARS-CoV-2 infection can cause cardiac dysfunction (Babapoor-Farrokhran et al. 2020). Some antiviral drugs have had a negative impact on cardiac functions (Zheng et al. 2020). Therefore, patients with cardiovascular diseases can also fall under high-risk groups for infection. Men

Table 4 A few known glucocorticoids

\begin{tabular}{ll}
\hline Drug candidate & Physiological effect \\
\hline Beclomethasone & Anti-inflammatory \\
Betamethasone & Anti-inflammatory \\
Budesonide & Anti-inflammatory \\
Dexamethasone & Anti-inflammatory and analgesic \\
Fludrocorticoid & Anti-inflammatory \\
Hydrocortisone & Anti-inflammatory \\
Methyl Prednisolone & Anti-inflammatory and immunosuppressive \\
Prednisone & Anti-inflammatory \\
Prednisolone & Anti-inflammatory and anti-cancer \\
Triamcinolone & Anti-inflammatory \\
\hline
\end{tabular}


over women are more vulnerable to the infection, suggesting hormonal regulation and natural immunity impact the condition (Agrawal et al. 2020). Surprisingly, the immune-mediated complement activation also contributes to the pathology of coronavirus infection (Gralinski et al. 2018). Therefore, it is viewed that innate immunity can aggravate the disease (Birra et al. 2020), whereas adaptive immunity can facilitate virus clearance (Paces et al. 2020). Since cellular immunity plays a crucial role in producing neutralising antibodies (Poonia and Kottilil 2020), understanding the immune correlations with host immunity appears essential.

An exciting intervention was made based on viral infection patterns in some parts of the world that immune crossreactivity protects patients from COVID-19 impact (Reche 2020). However, the explanation given for this was based on available epitope information from common viruses: those infected at different stages of adult life such as Herpes Simplex (HSV), Hepatitis B (HBV), Influenza B (IBV), Papilloma $(\mathrm{PaV})$, Epstein-Barr Virus (EBV), Human Cytomegalovirus (HCMV), Human Rhinovirus (HRV), Human Immunodeficiency Virus (HIV), etc. More interestingly, the interpretation was also made on early childhood vaccinations against Mumps Virus (MuV), Rubella Virus (RuV), Measles Virus $(\mathrm{MeV})$, and more. Although the suggested immune reactivity or immune responses between children and adults are different, childhood vaccinations appear to play a role against SARSCoV-2 infection (Beric-Stojsic et al. 2020; O'Neill and Netea 2020). Further, it is hypothesized that vaccinations from other viruses can prepare the immune system for subsequent infections (Letto 2020).

Malaria has been a more significant risk factor for some Asian countries and majorly sub-Saharan Africa (WHO 2019). Malaria can also induce cytokine storm. Hence antimalarial drugs may be effective against inflammation induced during COVID-19 (Gutman et al. 2020). It has been reviewed in previous sections how antimalarial drugs can work against COVID19. However, due to lockdown restrictions and poor economic conditions, several primary health care measures have been impacted, in turn impacting malaria and COVID-19 associated recovery (Zawawi et al. 2020; Meo et al. 2020). The lessons learned from the Ebola virus outbreak on malarial treatment warns us to avoid a similar situation during the COVID-19 pandemic (Walker et al. 2015; Paintsil 2020). Similarly, health care measures against cardiovascular diseases also need to be paid attention to (Lukhna et al. 2020). A study also analyses how low- and middle-income countries, including Africa, are affected by the COVID-19 pandemic with HIV and tuberculosis, in addition to malaria (Hogan et al. 2020).

\section{High rates of malignancies caused by infectious agents in populations with relatively low rates of COVID-19}

In earlier sections, we discussed that cancer patients are vulnerable to SARS-CoV-2 infections due to their low immunity from cancer itself or immunosuppressant chemotherapeutic interventions (Cannizzaro and Puglisi 2020). It reiterates that cancer patients are at high risk of COVID-19. In one of the early cohort studies, it was found that a significant number of COVID-positive individuals are cancer patients (Liang et al. 2020). The anoxic hypoxia upon SARS-CoV-2 infection is one of the causes of hepatitis and liver damage (Sun et al. 2020). Besides, acute hepatitis has been reported to occur before respiratory complications suggesting vulnerability of hepatitis patients to the COVID-19 risk and hepatocellular carcinoma (Wander et al. 2020; Wingrove et al. 2020). On the other hand, human papillomavirus (HPV) infections contribute to nearly $5 \%$ of human cancers and influence cancer immunotherapies (Castellsagué et al. 2017; Zhou et al. 2019). Cervical cancer caused by HPV majorly affects women compared to men (Bray et al. 2018). However, it is reported that due to the presence of ACE-2 receptors on all testicular cells, similar to SARS-CoV-1 that causes male infertility, SARS-CoV-2 is expected to affect the spermatogenesis (Vishvkarma and Rajender 2020; Batiha et al. 2020). Since cancer patients receiving chemotherapy are at high risk for COVID-19 disease due to immunosuppression, additional care is required for such patients (Zhang et al. 2020a, b; Dewan et al. 2020).

Kaposi's sarcoma herpesvirus/human herpesvirus 8 (KSHV/HHV8) infections can be primarily associated with low-grade cancers. However, they were also observed with endemic viral infections such as HIV (Radu and Pantanowitz 2013). It has been proposed that SARS-CoV-2 infections can enhance the oncolytic activity of the herpes virus, and thus contribute to disease morbidity (Chen et al. 2020a). HIV patients with compromised immune systems are at high risk of COVID-19 disease as HIV infection not only compromises the immune responses but also associates with cancer incidences (Ji and Lu 2017; Shiau et al. 2020). Considering the abundance of ACE2 receptors in the gastrointestinal tissues (Harmer et al. 2002), it has been shown that SARS-CoV-2 can affect the gastrointestinal system (Xiao et al. 2020). Since the gastric acids do not inactivate the virus, it is presumed that people affected with Helicobacter pylori (H. pylori) and those suffering from gastritis are more prone to SARS-CoV-2 infection (Uno 2020). These data suggest that aged individuals with cancer-associated viral infections such as HIV, HPV, and KSHV/KSHV8 and bacterial infections such as $H$. pylori are at high risk. 


\section{Summary and perspectives}

Triggering the immune responses against foreign bodies, chemicals, toxins, and microorganisms is a natural phenomenon of all living beings. At the same time, excessive stimulation of immune molecules elicits tissue damage and can lead to mortality. Lowering the inflammatory responses can minimise such damage and contribute to survival. The chronic inflammation observed in cancer incidences is beneficial for the spread of disease and will not result in rapid tissue damage or organ failure. However, certain anti-inflammatory drugs are shown to lower cancer incidences as they interfere with cancer growth and spread. The microorganism infections also trigger the host inflammatory response. Since the rate of proliferation and spread of microorganisms is inexhaustible, it can lead to acute inflammation and tissue damage. A set of pro-inflammatory cytokines aggravates the inflammation. Therefore, lowering or interfering with the uncontrolled synthesis of pro-inflammatory cytokines may reduce tissue damage or organ failure. An increase in anti-inflammatory cytokines that are counterproductive to the proinflammatory cytokines is necessary in immunological perseverance.

The inflammation associated with viral infection, in particular, respiratory disease, is a challenge to clinicians and researchers. The actual question arises as to which one to target first, the inflammation or infection. Although decreasing the viral load remains to be a prerequisite, the damage caused by acute inflammation warns that the inflammation should be addressed first. Since conventional anti-inflammatory drugs are just good enough to reduce the inflammatory responses, they are usually combined with antiviral drugs. Therefore, lowering the inflammatory response either alone or with antiviral drugs appears to be beneficial. In the COVID-19 disease, the increase in viral load or triggered cytokine storm is always unpredictable. There is no specific incubation period for individuals, and it can occur together. Therefore, the mortality rates associated with inflammation or cytokine storm are relatively high compared to the virus load itself. The life-saving approach suggested is to lower the inflammation either alone or in combination with antiviral drugs. Developing new antiviral drugs and their novel combinations is not feasible since studies related to the basic understanding of the SARS-CoV-2 virus are still on, which is due to high mutation rate or unpredictable patterns of infection (van Dorp et al. 2020; Chen et al. 2020b; Li et al. 2020b). The immediate available option is to repurpose available anticancer anti-inflammatory drugs against COVID-19 associated inflammation. The comprehensive coverage of known anti-inflammatory agents already in the clinical trials against cancer has been reviewed in earlier sections (Di Lorenzo et al. 2020; Gougis et al. 2020). The advantages and consequences of using such drugs in the clinic are discussed in this review in detail.

COVID-19 pandemic is rapidly spreading through all nations, and in some parts, confronting in waves. Though there are differences of opinion in using anti-inflammatory and anticancer drugs against COVID-19, the success stories reiterate that they are beneficial in lowering the mortality rates. Since several such studies are still in the clinical level, in due course of time, with appropriate demographic, disease severity versus mortality, with and without anti-inflammatory drugs, they may provide conclusive and confirmative information. The repurposing of drugs such as chloroquine, non-steroidal anti-inflammatory drugs, glucocorticoids, etc. are promising for COVID-19 either alone or in combination. However, these drugs should be used with caution since prolonged suppression of the immune system can invite other opportunistic infections to occur. A particular window period and a moderate dose but not higher amounts are being suggested (Russell et al. 2020). Based on the available information, we propose how low, medium, and increased cytokine storm responses can be modulated by glucocorticoids (Fig. 7).

It is known that individuals with autoimmune disorders are more prone to cancer, where compromised immune responses act in favor of cancer (Giat et al. 2017). SARS$\mathrm{CoV}-2$ has been shown to induce autoimmunity (Halpert and Shoenfeld 2020; Ehrenfeld et al. 2020), which may invite opportunistic diseases such as cancer with long-lasting complications even with decreased viral load. Therefore, counteracting the inflammatory storm should be prioritised while subsequent treatments are directed to reduce the viral load or spread. Accordingly, similar to cancer patients, the patients with autoimmune disorders can also be considered as high-risk groups (Lagadinou et al. 2020) and may need anti-inflammatory drug treatments, however, in a case-specific manner. 


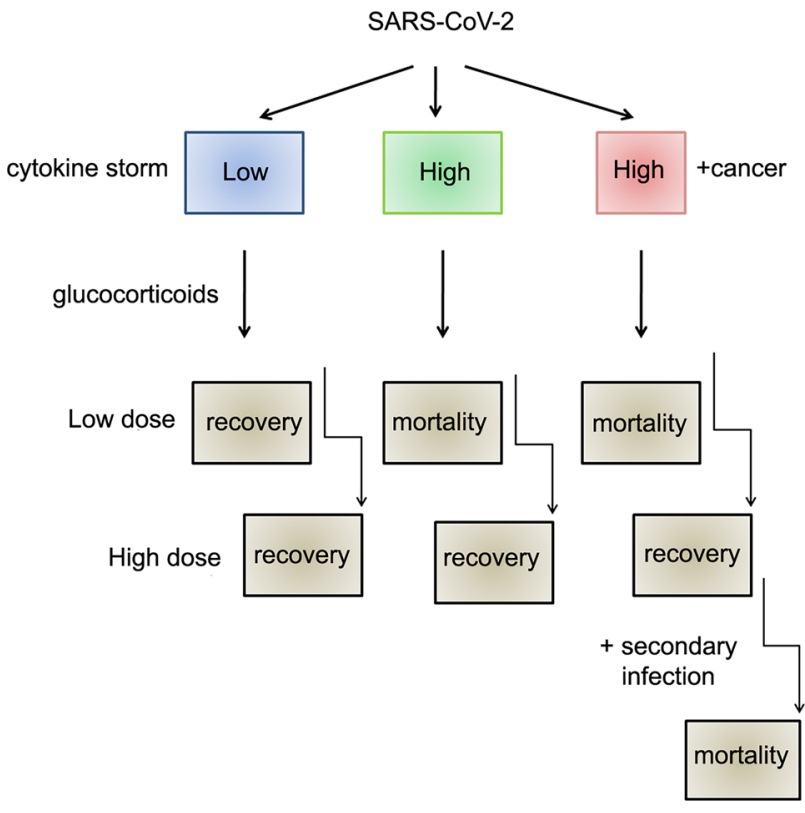

Fig. 7 A proposed hypothesis of anti-inflammatory drugs for cancer patients infected with SARS-CoV-2. The effect of glucocorticoid treatment against SARS-CoV-2 induced cytokine storm in low- and high-level infection versus cancer patients is described. The glucocorticoid treatment can compromise the cytokine storm from both low- and high-level infection, probably leading to no or decreased mortality rates and thus, patient recovery. The glucocorticoid treatment appears to compromise high-level infection in cancer patients; however, it can lead to secondary infections due to low or compromised immune responses, resulting in increased mortality rates. Since cancer patients infected with SARS-CoV-2 may not respond to lower doses of anti-inflammatory drugs, increasing the drug dose can invite other opportunistic infections to occur. Therefore, the predicted strategy advises the systematic and context-based use of glucocorticoids for the treatment of cancer patients infected with SARS-CoV-2

Acknowledgements ASS would like to thank Drs Khanderao Paithankar and Amash Vijayalakshmi for the critical comments on the manuscript. CSIR-CCMB has supported the work.

\section{Declaration}

Conflict of Interest The author declares no conflict of interest.

\section{References}

Acharya A, Kevadiya BD, Gendelman HE, Byrareddy SN (2020) SARS-CoV-2 infection leads to neurological dysfunction. J Neuroimmune Pharmacol 15:167-173. https://doi.org/10.1007/ s11481-020-09924-9

Adams GP, Weiner LM (2005) Monoclonal antibody therapy of cancer. Nat Biotechnol 23:1147-1157. https://doi.org/10.1038/nbt1137

Agrawal H, Das N, Nathani S, Saha S, Saini S, Kakar SS, Roy P (2020) An assessment on impact of COVID-19 infection in a gender specific manner. Stem Cell Rev Rep 7:1-19. https://doi. org/10.1007/s12015-020-10048-z

Al-Bari MA (2015) Chloroquine analogues in drug discovery: new directions of uses, mechanisms of actions and toxic manifestations from malaria to multifarious diseases. J Antimicrob Chemother 70:1608-1621. https://doi.org/10.1093/jac/dkv018 (Epub 2015 Feb 17)

Alkholy UM, Salama ME, Mahmoud H, Taher A, Elsayes KM (2020) Could Bordetella pertussis vaccine protects against coronavirus COVID-19? J Glob Antimicrob Resist 22:803-805. https://doi. org/10.1016/j.jgar.2020.07.005

Allegra A, Pioggia G, Tonacci A, Musolino C, Gangemi S (2020) Cancer and SARS-CoV-2 infection: diagnostic and therapeutic challenges. Cancers 12:1581. https://doi.org/10.3390/cance rs12061581

Andreansky S, He B, van Cott J, McGhee J, Markert JM, Gillespie GY, Roizman B, Whitley RJ (1998) Treatment of intracranial gliomas in immunocompetent mice using herpes simplex viruses that express murine interleukins. Gene Ther 5:121130. https://doi.org/10.1038/sj.gt.3300550

Araldi RP, Sant'Ana TA, Módolo DG, de Melo TC, Spadacci-Morena DD, de Cassia SR, Cerutti JM, de Souza EB (2018) The human papillomavirus (HPV)-related cancer biology: an overview. Biomed Pharmacother 106:1537-1556. https://doi.org/10.1016/j. biopha.2018.06.149

Arias JI, Aller MA, Arias J (2007) Cancer cell: using inflammation to invade the host. Mol Cancer 6:29. https://doi.org/10.1186/ 1476-4598-6-29

Arlehamn CSL, Sette A, Peters B (2020) Lack of evidence for BCG vaccine protection from severe COVID-19. Proc Natl Acad Sci USA 117:25203-25204. https://doi.org/10.1073/pnas.20167 33117

Ashley NT, Weil ZM, Nelson RJ (2012) Inflammation: mechanisms, costs, and natural variation. Ann Rev Ecol Evol Syst 43:385-406

Babapoor-Farrokhran S, Gill D, Walker J, Rasekhi RT, Bozorgnia B, Amanullah A (2020) Myocardial injury and COVID-19: oossible mechanisms. Life Sci 253:117723. https://doi.org/10.1016/j.lfs. 2020.117723

Bagga S, Bouchard MJ (2014) Cell cycle regulation during viral infection. Methods Mol Biol 1170:165-227. https://doi.org/10.1007/ 978-1-4939-0888-2 10

Balkwill F (2006) TNF-alpha in promotion and progression of cancer. Cancer Metastasis Rev 25:409-416. https://doi.org/10.1007/ s10555-006-9005-3

Balkwill F, Mantovani A (2001) Inflammation and cancer: back to Virchow? Lancet 357:539-545. https://doi.org/10.1016/S01406736(00)04046-0

Batiha O, Al-Deeb T, Al-Zoubi E, Alsharu E (2020) Impact of COVID-19 and other viruses on reproductive health. Andrologia 52:e13791. https://doi.org/10.1111/and.13791

Beigel JH, Farrar J, Han AM, Hayden FG, Hyer R, de Jong MD, Lochindarat S, Nguyen TK, Nguyen TH, Tran TH, Nicoll A, Touch S, Yuen KY (2005) Writing avian influenza A (H5N1) infection in humans. Committee of the World Health Organization (WHO) Consultation on Human Influenza A/H5. N Engl J Med 353:1374-1385

Beigel JH, Tomashek KM, Dodd LE, Mehta AK, Zingman BS, Kalil AC, Hohmann E, Chu HY, Luetkemeyer A, Kline S, de Castilla DL, Finberg RW, Dierberg K, Tapson V, Hsieh L, Patterson TF, Paredes R, Sweeney DA, Short WR, Touloumi G, Lye DC, Ohmagari N, Oh MD, Ruiz-Palacios GM, Benfield T, Fätkenheuer G, Kortepeter MG, Atmar RL, Creech CB, Lundgren J, Babiker AG, Pett S, Neaton JD, Burgess TH, Bonnett T, Green M, Makowski M, Osinusi A, Nayak S, Lane HC (2020) Remdesivir for the treatment of COVID-19-preliminary report. N Engl J Med. https://doi.org/10.1056/NEJMoa2007764 
Benkheil M, Paeshuyse J, Neyts J, Van Haele M, Roskams T, Liekens S (2018) HCV-induced EGFR-ERK signaling promotes a proinflammatory and pro-angiogenic signature contributing to liver cancer pathogenesis. Biochem Pharmacol 155:305-315. https:// doi.org/10.1016/j.bcp.2018.07.011

Ben-Zvi I, Kivity S, Langevitz P, Shoenfeld Y (2012) Hydroxychloroquine: from malaria to autoimmunity. Clin Rev Allergy Immunol 42:145-153. https://doi.org/10.1007/s12016-010-8243-x

Berg J, Zscheppang K, Fatykhova D, Tönnies M, Bauer TT, Schneider P, Neudecker J, Rückert JC, Eggeling S, Schimek M, Gruber AD, Suttorp N, Hippenstiel S, Hocke AC (2017) Tyk2 as a target for immune regulation in human viral/bacterial pneumonia. Eur Respir J 50:1601953. https://doi.org/10.1183/13993003. 01953-2016

Beric-Stojsic B, Kalabalik-Hoganson J, Rizzolo D, Roy S (2020) Childhood immunization and COVID-19: an early narrative review. Front Public Health 8:587007. https://doi.org/10.3389/fpubh. 2020.587007

Bianchi ME (2007) DAMPs, PAMPs and alarmins: all we need to know about danger. J Leukoc Biol 81:1-5. https://doi.org/10.1189/jlb. 0306164

Bild AH, Yao G, Chang JT, Wang Q, Potti A, Chasse D, Joshi MB, Harpole D, Lancaster JM, Berchuck A, Olson JA Jr, Marks JR, Dressman HK, West M, Nevins JR (2006) Oncogenic pathway signatures in human cancers as a guide to targeted therapies. Nature 439:353-357. https://doi.org/10.1038/nature04296

Birra D, Benucci M, Landolfi L, Merchionda A, Loi G, Amato P, Licata G, Quartuccio L, Triggiani M, Moscato P (2020) COVID 19: a clue from innate immunity. Immunol Res 68:161-168. https:// doi.org/10.1007/s12026-020-09137-5

Blackadar CB (2016) Historical review of the causes of cancer. World J Clin Oncol 7:54-86. https://doi.org/10.5306/wjco.v7.i1.54

Blankenstein T, Coulie PG, Gilboa E, Jaffee EM (2012) The determinants of tumour immunogenicity. Nat Rev Cancer 12:307-313. https://doi.org/10.1038/nrc3246

Boehm T, Swann JB (2014) Origin and evolution of adaptive immunity. Annu Rev Anim Biosci 2:259-283. https://doi.org/10.1146/annur ev-animal-022513-114201

Boomer JS, To K, Chang KC, Takasu O, Osborne DF, Walton AH, Bricker TL, Jarman SD 2nd, Kreisel D, Krupnick AS, Srivastava A, Swanson PE, Green JM, Hotchkiss RS (2011) Immunosuppression in patients who die of sepsis and multiple organ failure. JAMA 306:2594-2605

Bourreau E, Gardon J, Pradinaud R, Pascalis H, Prévot-Linguet G, Kariminia A, Pascal L (2003) Th2 responses predominate during the early phases of infection in patients with localized cutaneous leishmaniasis and precede the development of Th1 responses. Infect Immun 71:2244-2246. https://doi.org/10.1128/iai.71.4. 2244-2246.2003

Bray F, Ferlay J, Soerjomataram I, Siegel RL, Torre LA, Jemal A (2018) Global cancer statistics 2018: GLOBOCAN estimates of incidence and mortality worldwide for 36 cancers in 185 countries. CA Cancer J Clin 68:394-424. https://doi.org/10.3322/ caac. 21492

Brun-Buisson C, Richard JC, Mercat A, Thiebaut AC, Brochard L (2011) Group R-SAHNvR. Early corticosteroids in severe influenza A/H1N1 pneumonia and acute respiratory distress syndrome. Am J Respir Crit Care Med 183:1200-1206. https://doi. org/10.1164/rccm.201101-0135OC

Butel JS (2000) Viral carcinogenesis: revelation of molecular mechanisms and etiology of human disease. Carcinogenesis 21:405426. https://doi.org/10.1093/carcin/21.3.405

Butler MJ, Barrientos RM (2020) The impact of nutrition on COVID19 susceptibility and long-term consequences. Brain Behav Immun 87:53-54. https://doi.org/10.1016/j.bbi.2020.04.040
Buxant F, Engohan-Aloghe C, Noël JC (2010) Estrogen receptor, progesterone receptor, and glucocorticoid receptor expression in normal breast tissue, breast in situ carcinoma, and invasive breast cancer. Appl Immunohistochem Mol Morphol 18:254257. https://doi.org/10.1097/PAI.0b013e3181c10180

Caly L, Druce JD, Catton MG, Jans DA, Wagstaff KM (2020) The FDA-approved drug ivermectin inhibits the replication of SARSCoV-2 in vitro. Antivir Res 178:104787

Cannizzaro R, Puglisi F (2020) Covid-19 and cancer patients: choosing wisely is the key. Dig Liver Dis 52:595-596. https://doi.org/10. 1016/j.dld.2020.03.030

Castellsagué X (2008) Natural history and epidemiology of HPV infection and cervical cancer. Gynecol Oncol 110:S4-7. https://doi. org/10.1016/j.ygyno.2008.07.045

Castellsagué X, Mena M, Alemany L (2017) Epidemiology of HPV-positive tumors in Europe and in the World. Recent Results Cancer Res 206:27-35. https://doi.org/10.1007/ 978-3-319-43580-0_2

Catanzaro M, Fagiani F, Racchi M, Corsini E, Govoni S, Lanni C (2020) Immune response in COVID-19: addressing a pharmacological challenge by targeting pathways triggered by SARSCoV-2. Signal Transduct Target Ther 5:84. https://doi.org/10. 1038/s41392-020-0191-1

Caterina MJ, Julius D (2001) The vanilloid receptor: a molecular gateway to the pain pathway. Annu Rev Neurosci 24:487-517. https://doi.org/10.1146/annurev.neuro.24.1.487

Chaplin DD (2010) Overview of the immune response. J Allergy Clin Immunol 125(2 Suppl 2):S3-S23. https://doi.org/10.1016/j.jaci. 2009.12.980

Chaudhry H, Zhou J, Zhong Y, Ali MM, McGuire F, Nagarkatti PS, Nagarkatti M (2013) Role of cytokines as a double-edged sword in sepsis. In Vivo (Athens, Greece) 27:669-684

Chen DS, Mellman I (2013) Oncology meets immunology: the cancerimmunity cycle. Immunity 39:1-10. https://doi.org/10.1016/j. immuni.2013.07.012

Chen J, Lau YF, Lamirande EW, Paddock CD, Bartlett JH, Zaki SR, Subbarao K (2010) Cellular immune responses to severe acute respiratory syndrome coronavirus (SARS-CoV) infection in senescent BALB/c mice: CD4+ T cells are important in control of SARS-CoV infection. J Virol 84:1289-1301. https://doi.org/ 10.1128/JVI.01281-09

Chen J, Dai L, Barrett L, Post SR, Qin Z (2020a) SARS-CoV-2 proteins and anti-COVID-19 drugs induce lytic reactivation of an oncogenic virus. bioRxiv. https://doi.org/10.1101/2020.10.02.324228

Chen J, Wang R, Wang M, Wei GW (2020b) Mutations strengthened SARS-CoV-2 infectivity. J Mol Biol 432:5212-5226. https://doi. org/10.1016/j.jmb.2020.07.009

Cheng F, Rao S, Mehra R (2020) COVID-19 treatment: combining anti-inflammatory and antiviral therapeutics using a networkbased approach. Cleve Clin J Med. https://doi.org/10.3949/ccjm. 87 a.ccc037

Chulpanova DS, Kitaeva KV, Green AR, Rizvanov AA, Solovyeva VV (2020) Molecular aspects and future perspectives of cytokinebased anticancer immunotherapy. Front Cell Dev Biol 8:402. https://doi.org/10.3389/fcell.2020.00402

Ciliberto G, Mancini R, Paggi MG (2020) Drug repurposing against COVID-19: focus on anticancer agents. J Exp Clin Cancer Res 39:86. https://doi.org/10.1186/s13046-020-01590-2

Cinatl J Jr, Michaelis M, Morgenstern B, Doerr HW (2005) Highdose hydrocortisone reduces expression of the pro-inflammatory chemokines CXCL8 and CXCL10 in SARS coronavirus-infected intestinal cells. Int J Mol Med 15(2):323-327

Citron F, Perelli L, Deem AK, Genovese G, Viale A (2020) Leukotrienes, a potential target for COVID-19. PLEFA 161:102174. https://doi.org/10.1016/j.plefa.2020.102174 
Conlon KC, Miljkovic MD, Waldmann TA, Doerr HW (2019) Cytokines in the treatment of cancer. J Interferon Cytokine Res 39:6-21. https://doi.org/10.1089/jir.2018.0019

Convertino I, Tuccori M, Ferraro S, Valdiserra G, Cappello E, Focosi D, Blandizzi C (2020) Exploring pharmacological approaches for managing cytokine storm associated with pneumonia and acute respiratory distress syndrome in COVID-19 patients. Crit Care 24:331. https://doi.org/10.1186/s13054-020-03020-3

Cook AM, McDonnell AM, Lake RA, Nowak AK (2015) Dexamethasone co-medication in cancer patients undergoing chemotherapy causes substantial immunomodulatory effects with implications for chemo-immunotherapy strategies. OncoImmunology 5:https://doi.org/10.1080/2162402X.2015.1066062

Cooper MD, Alder MN (2006) The evolution of adaptive immune systems. Cell 124:815-822. https://doi.org/10.1016/j.cell.2006. 02.001

Cooper AM, Khader SA (2008) The role of cytokines in the initiation, expansion, and control of cellular immunity to tuberculosis. Immunol Rev 226:191-204. https://doi.org/10.1111/j.1600065X.2008.00702.X

Cortegiani A, Ippolito M, Greco M, Granone V, Protti A, Gregoretti C, Giarratano A, Einav S, Cecconi M (2020) Rationale and evidence on the use of tocilizumab in COVID-19: a systematic review. Pulmonology. https://doi.org/10.1016/j.pulmoe.2020.07.003

Costela-Ruiz VJ, Illescas-Montes R, Puerta-Puerta JM, Ruiz C, Melguizo-Rodríguez L (2020) SARS-CoV-2 infection: the role of cytokines in COVID-19 disease. Cytokine Growth Factor Rev. https://doi.org/10.1016/j.cytogfr.2020.06.001

Costello RT, Gastaut JA, Olive D (1999) Tumour escape from immune surveillance. Arch Immunol Ther Exp (Warsz) 47:83-88

Coussens LM, Werb Z (2002) Inflammation and cancer. Nature 420:860-867. https://doi.org/10.1038/nature01322

Curtis J (2006) Corticosteroids and kidney transplantation. Clin J Am Soc Nephrol 1:907-908. https://doi.org/10.2215/CJN.02340706

Danilova N (2006) The evolution of immune mechanisms. J Exp Zool B Mol Dev Evol 306:496-520. https://doi.org/10.1002/jez.b. 21102 (PMID: 16619242)

Das UN (2020) Can bioactive lipids inactivate coronavirus (COVID19)? Arch Med Res 51:282-286. https://doi.org/10.1016/j.arcmed.2020.03.004

Dayaram T, Marriott SJ (2008) Effect of transforming viruses on molecular mechanisms associated with cancer. J Cell Physiol 216:309-314. https://doi.org/10.1002/jcp.21439

De Lucena DD, Rangel ÉB (2018) Glucocorticoids use in kidney transplant setting. Expert Opin Drug Metab Toxicol 14:1023-1041. https://doi.org/10.1080/17425255.2018.1530214

Deeb RS, Upmacis RK, Lamon BD, Gross SS, Hajjar DP (2008) Maintaining equilibrium by selective targeting of cyclooxygenase pathways: promising offensives against vascular injury. Hypertension 51:1-7. https://doi.org/10.1161/HYPERTENSIONAHA. 107.092866

Delbue S, Comar M, Ferrante P (2017) Review on the role of the human Polyomavirus JC in the development of tumours. Infect Agents Cancer 12:10. https://doi.org/10.1186/s13027-017-0122-0

D’Elia RV, Harrison K, Oyston PC, Lukaszewski RA, Clark GC (2013) Targeting the "cytokine storm" for therapeutic benefit. Clin Vaccine Immunol 20:319-327. https://doi.org/10.1128/CVI. 00636-12

Derwand R, Scholz M (2020) Does zinc supplementation enhance the clinical efficacy of chloroquine/hydroxychloroquine to win today's battle against COVID-19? Med Hypotheses 142:109815. https://doi.org/10.1016/j.mehy.2020.109815

Desai A, Sachdeva S, Parekh T, Desai R (2020) COVID-19 and cancer: lessons from a pooled meta-analysis. JCO Glob Oncol 6:557559. https://doi.org/10.1200/GO.20.00097
Dewan A, Mitra S, Aggarwal S, Barik S, Kaur I, Umesh P, Dewan R (2020) Management of cervical cancer during the corona virus disease-19 (COVID-19) era. Br J Radiol. https://doi.org/10.1259/ bjr.20200686

Dheda K, Limberis JD, Pietersen E, Phelan J, Esmail A, Lesosky M, Fennelly KP, Te Riele J, Mastrapa B, Streicher EM, Dolby T, Abdallah AM, Ben-Rached F, Simpson J, Smith L, Gumbo T, van Helden P, Sirgel FA, McNerney R, Theron G, Warren RM (2017) Outcomes, infectiousness, and transmission dynamics of patients with extensively drug-resistant tuberculosis and home discharged patients with programmatically incurable tuberculosis: a prospective cohort study. Lancet Respir Med 5:269-281. https://doi.org/10.1016/S2213-2600(16)30433-7

Di Lorenzo G, Di Trolio R, Kozlakidis Z, Busto G, Ingenito C, Buonerba L, Ferrara C, Libroia A, Ragone G, Ioio CD, Savastano B, Polverino M, De Falco F, Iaccarino S, Leo E (2020) COVID 19 therapies and anti-cancer drugs: a systematic review of recent literature. Crit Rev Oncol/Hematol 152:102991. https://doi.org/ 10.1016/j.critrevonc.2020.102991

Dinarello CA (2007) Historical insights into cytokines. Eur J Immunol 37:S34-S45. https://doi.org/10.1002/eji.200737772

Dixit SB, Zirpe KG, Kulkarni AP, Chaudhry D, Govil D, Mehta Y, Jog SA, Khatib KI, Pandit RA, Samavedam S, Rangappa P, Bandopadhyay S, Shrivastav O, Mhatre U (2020) Current approaches to COVID-19: therapy and prevention. Ind J Crit Care Med 24:838-846. https://doi.org/10.5005/jp-journals-10071-23470

Dranoff G (2004) Cytokines in cancer pathogenesis and cancer therapy. Nat Rev Cancer 4:11-22. https://doi.org/10.1038/nrc1252

Dubey MJ, Ghosh R, Chatterjee S, Biswas P, Chatterjee S, Dubey S (2020) COVID-19 and addiction. Diabetes Metab Syndr 14:817823. https://doi.org/10.1016/j.dsx.2020.06.008

Dunlop RJ, Campbell CW (2000) Cytokines and advanced cancer. J Pain Symptom Manag 20:214-232. https://doi.org/10.1016/ s0885-3924(00)00199-8)

Ehrenfeld M, Tincani A, Andreoli L, Cattalini M, Greenbaum A, Kanduc D, Alijotas-Reig J, Zinserling V, Semenova N, Amital H, Shoenfeld Y (2020) Covid-19 and autoimmunity. Autoimmun Rev 19:102597. https://doi.org/10.1016/j.autrev.2020.102597

El-Tallawy SN, Nalamasu R, Pergolizzi JV, Gharibo C (2020) Pain management during the COVID-19 pandemic. Pain Ther. https:// doi.org/10.1007/s40122-020-00190-4

Escobar LE, Molina-Cruz A, Barillas-Mury C (2019) BCG vaccine protection from severe coronavirus disease 2019 (COVID-19). Proc Natl Acad Sci USA 117:17720-17726. https://doi.org/10. 1073/pnas.2008410117

Fan H (2011) Cell transformation by RNA viruses: an overview. Viruses 3:858-860. https://doi.org/10.3390/v3060858

Fantuzzi G, Ghezzi P (1993) Glucocorticoids as cytokine inhibitors: role in neuroendocrine control and therapy of inflammatory diseases. Mediat Inflamm 2:263-270. https://doi.org/10.1155/S0962 935193000365

Farhat RM, Mousa MA, Daas EJ, Glassberg MK (2020) Treatment of COVID-19: perspective on convalescent plasma transfusion. Front Med (Lausanne) 7:435. https://doi.org/10.3389/fmed.2020. 00435

Farooqi F, Dhawan N, Morgan R, Dinh J, Nedd K, Yatzkan G (2020) Treatment of severe COVID-19 with tocilizumab mitigates cytokine storm and averts mechanical ventilation during acute respiratory distress: a case report and literature review. Trop Med Infect Dis 5:112. https://doi.org/10.3390/tropicalmed5030112

Fey SJ, Larsen PM (1988) DNA viruses and human cancer. Cancer Lett 41:1-19. https://doi.org/10.1016/0304-3835(88)90049-3

Florence JM, Krupa A, Booshehri LM, Davis SA, Matthay MA, Kurdowska AK (2018) Inhibiting Bruton's tyrosine kinase rescues mice from lethal influenza-induced acute lung injury. Am J 
Physiol Lung Cell Mol Physiol 315:L52-L58. https://doi.org/ 10.1152/ajplung.00047.2018

Frohman EM, Villemarette-Pittman NR, Cruz RA, Longmuir R, Rowe V, Rowe ES, Varkey TC, Steinman L, Zamvil SS, Frohman TC (2020) Part II high-dose methotrexate with leucovorin rescue for severe COVID-19: an immune stabilization strategy for SARS-CoV-2 induced "PANIC" attack. J Neurol Sci 415:116935. https://doi.org/10.1016/j.jns.2020.116935

Fu LQ, Wang SB, Cai MH, Wang XJ, Chen JY, Tong XM, Chen XY, Mou XZ (2019) Recent advances in oncolytic virus-based cancer therapy. Virus Res 270:197675. https://doi.org/10.1016/j. virusres.2019.197675

Fung TS, Liu DX (2017) Activation of the c-Jun $\mathrm{NH}_{2}$-terminal kinase pathway by coronavirus infectious bronchitis virus promotes apoptosis independently of c-Jun. Cell Death Dis 8:3215. https://doi.org/10.1038/s41419-017-0053-0

Funk CD, Ardakani A (2020) A novel strategy to mitigate the hyperinflammatory response to COVID-19 by targeting leukotrienes. Fron Pharmacol 11:1214. https://doi.org/10.3389/fphar.2020. 01214

Fuss I, Schlaak J, Meyer Zum Buschenfelde K, Strober W, Neurath M (1999) Azathioprine can modulate immunosuppression through an IL-10 mediated mechanism. J Pediatr Gastroenterol Nutr 29:490

Gaglia MM, Munger K (2018) More than just oncogenes: mechanisms of tumorigenesis by human viruses. Curr Opin Virol 32:48-59. https://doi.org/10.1016/j.coviro.2018.09.003

Galeotti C, Bayry J (2020) Autoimmune and inflammatory diseases following COVID-19. Nat Rev Rheumatol 16:413-414. https:// doi.org/10.1038/s41584-020-0448-7

Gao W, Xiong Y, Li Q, Yang H (2017) Inhibition of toll-like receptor signaling as a promising therapy for inflammatory diseases: a journey from molecular to nano therapeutics. Front Physiol 8:508. https://doi.org/10.3389/fphys.2017.00508

Gatza ML, Chandhasin C, Ducu RI, Marriott SJ (2005) Impact of transforming viruses on cellular mutagenesis, genome stability, and cellular transformation. Environ Mol Mutagen 45:304325. https://doi.org/10.1002/em.20088

Gautret P, Lagier JC, Parola P, Hoang VT, Meddeb L, Mailhe M, Doudier B, Courjon J, Giordanengo V, Vieira VE, Tissot Dupont H, Honoré S, Colson P, Chabrière E, La Scola B, Rolain JM, Brouqui P, Raoult D (2020) Hydroxychloroquine and azithromycin as a treatment of COVID-19: results of an open-label non-randomized clinical trial. Int $\mathbf{J}$ Antimicrob Agents 56:105949. https://doi.org/10.1016/j.ijantimicag.2020. 105949

Gentry CA, Humphrey MB, Thind SK, Hendrickson SC, Kurdgelashvili G, Williams RJ 2nd (2020) Long-term hydroxychloroquine use in patients with rheumatic conditions and development of SARS-CoV-2 infection: a retrospective cohort study. Lancet Rheumatol 2:e689-e697. https://doi.org/10.1016/S26659913(20)30305-2

Germano G, Allavena P, Mantovani A (2008) Cytokines as a key component of cancer-related inflammation. Cytokine 43:374-379. https://doi.org/10.1016/j.cyto.2008.07.014

Giat E, Ehrenfeld M, Shoenfeld Y (2017) Cancer and autoimmune diseases. Autoimmun Rev 16:1049-1057. https://doi.org/10.1016/j. autrev.2017.07.022

Giudice V, Pagliano P, Vatrella A, Masullo A, Poto S, Polverino BM, Gammaldi R, Maglio A, Sellitto C, Vitale C, Serio B, Cuffa B, Borrelli A, Vecchione C, Filippelli A, Selleri C (2020) Combination of ruxolitinib and eculizumab for treatment of severe SARSCoV-2-related acute respiratory distress syndrome: a controlled study. Front Pharmacol 11:857. https://doi.org/10.3389/fphar. 2020.00857
Goldszmid RS, Dzutsev A, Trinchieri G (2014) Host immune response to infection and cancer: unexpected commonalities. Cell Host Microb 15:295-305. https://doi.org/10.1016/j.chom.2014.02.003

Gonçalves PH, Uldrick TS, Yarchoan R (2017) HIV-associated Kaposi sarcoma and related diseases. AIDS 31:1903-1916. https://doi. org/10.1097/QAD.0000000000001567

Gonzalez H, Hagerling C, Werb Z (2018) Roles of the immune system in cancer: from tumour initiation to metastatic progression. Genes Dev 32:1267-1284. https://doi.org/10.1101/gad.314617. 118

Gougis P, Fenioux C, Funck-Brentano C, Veyri M, Gligorov J, Solas C, Spano JP (2020) Anticancer drugs and COVID-19 antiviral treatments in patients with cancer: what can we safely use? Eur J Cancer 136:1-3. https://doi.org/10.1016/j.ejca.2020.05.027

Graham GG, Scott KF (2005) Mechanism of action of paracetamol. Am J Ther 12:46-55. https://doi.org/10.1097/00045391-20050 1000-00008

Gralinski LE, Sheahan TP, Morrison TE, Menachery VD, Jensen K, Leist SR, Whitmore A, Heise MT, Baric RS (2018) Complement activation contributes to severe acute respiratory syndrome coronavirus pathogenesis. mBio 9:e01753-e1818. https://doi.org/10. 1128/mBio.01753-18

Greenstein S, Ghias K, Krett NL, Rosen ST (2002) Mechanisms of glucocorticoid-mediated Apoptosis in hematological malignancies. Clin Cancer Res 8:1681-1694

Greten FR, Grivennikov SI (2019) Inflammation and cancer: triggers, mechanisms, and consequences. Immunity 51:27-41. https://doi. org/10.1016/j.immuni.2019.06.025

Guedan S, Alemany R (2018) CAR-T cells and oncolytic viruses: joining forces to overcome the solid tumour challenge. Front Immunol 9:2460. https://doi.org/10.3389/fimmu.2018.02460

Gulley JL, Madan RA, Pachynski R, Mulders P, Sheikh NA, Trager J, Drake CG (2017) Role of antigen spread and distinctive characteristics of immunotherapy in cancer treatment. J Natl Cancer Inst 109:djw261. https://doi.org/10.1093/jnci/djw261

Guo T, Fan Y, Chen M, Wu X, Zhang L, He T, Wang H, Wan J, Wang $X, \mathrm{Lu} Z$ (2020) Cardiovascular implications of fatal outcomes of patients with coronavirus disease 2019 (COVID-19). JAMA Cardiol 5:811-818. https://doi.org/10.1001/jamacardio.2020.1017

Gutman JR, Lucchi NW, Cantey PT, Steinhardt LC, Samuels AM, Kamb ML, Kapella BK, McElroy PD, Udhayakumar V, Lindblade KA (2020) Malaria and parasitic neglected tropical diseases: potential syndemics with COVID-19? Am J Trop Med Hyg 103:572-577. https://doi.org/10.4269/ajtmh.20-0516

Halpert G, Shoenfeld Y (2020) SARS-CoV-2, the autoimmune virus. Autoimmun Rev 19:102695. https://doi.org/10.1016/j.autrev. 2020.102695

Hanahan D, Weinberg RA (2011) Hallmarks of cancer: the next generation. Cell 144:646-674. https://doi.org/10.1016/j.cell.2011. 02.013

Hanna TP, Evans GA, Booth CM (2020) Cancer, COVID-19 and the precautionary principle: prioritizing treatment during a global pandemic. Nat Rev Clin Oncol 17:268-270. https://doi.org/10. 1038/s41571-020-0362-6

Harmer D, Gilbert M, Borman R, Clark KL (2002) Quantitative mRNA expression profiling of ACE 2, a novel homologue of angiotensin converting enzyme. FEBS Lett 532:107-110. https://doi.org/10. 1016/s0014-5793(02)03640-2

Hashemi Goradel N, Najafi M, Salehi E, Farhood B, Mortezaee K (2019) Cyclooxygenase-2 in cancer: a review. J Cell Physiol 234:5683-5699. https://doi.org/10.1002/jcp.27411

Hewitt EW (2003) The MHC class I antigen presentation pathway: strategies for viral immune evasion. Immunology 110:163-169. https://doi.org/10.1046/j.1365-2567.2003.01738.x

Hippisley-Cox J, Young D, Coupland C, Channon KM, Tan PS, Harrison DA, Rowan K, Aveyard P, Pavord ID, Watkinson PJ 
(2020) Risk of severe COVID-19 disease with ACE inhibitors and angiotensin receptor blockers: cohort study including 8.3 million people. Heart 106(19):1503-1511. https://doi.org/10. 1136/heartjnl-2020-317393

Hofseth LJ, Ying L (2006) Identifying and defusing weapons of mass inflammation in carcinogenesis. Biochim Biophys Acta 1765:74-84. https://doi.org/10.1016/j.bbcan.2005.08.005

Hogan AB, Jewell BL, Sherrard-Smith E, Vesga JF, Watson OJ, Whittaker C, Hamlet A, Smith JA, Winskill P, Verity R, Baguelin M, Lees JA, Whittles LK, Ainslie KEC, Bhatt S, Boonyasiri A, Brazeau NF, Cattarino L, Cooper LV, Coupland H, Cuomo-Dannenburg G, Dighe A, Djaafara BA, Donnelly CA, Eaton JW, van Elsland SL, FitzJohn RG, Fu H, Gaythorpe KAM, Green W, Haw DJ, Hayes S, Hinsley W, Imai N, Laydon DJ, Mangal TD, Mellan TA, Mishra S, Nedjati-Gilani G, Parag KV, Thompson HA, Unwin HJT, Vollmer MAC, Walters CE, Wang H, Wang Y, Xi X, Ferguson NM, Okell LC, Churcher TS, Arinaminpathy N, Ghani AC, Walker PGT, Hallett TB (2020) Potential impact of the COVID-19 pandemic on HIV, tuberculosis, and malaria in low-income and middle-income countries: a modelling study. Lancet Glob Health 8:e1132e1141. https://doi.org/10.1016/S2214-109X(20)30288-6

Holdsworth SR, Gan PY (2015) Cytokines: names and numbers you should care about. Clin J Am Soc Nephrol 10:2243-2254. https://doi.org/10.2215/CJN.07590714

Hu Y, Tan S, Yin E, Yang Y, Wu H, Wei G, Su J, Cui Q, Jin A, Yang L, Fu S, Zhou J, Qiu L, Zhang X, Liang A, Jing H, Li Y, Blaise D, Mohty M, Nagler A, Huang H (2020) CAR T-cell treatment during the COVID-19 pandemic: management strategies and challenges. Curr Res Transl Med 68:111-118. https://doi.org/ 10.1016/j.retram.2020.06.003

Ichiyama $\mathrm{T}$, Isumi $\mathrm{H}$, Ozawa $\mathrm{H}$, Matsubara $\mathrm{T}$, Morishima $\mathrm{T}$, Furukawa S (2003) Cerebrospinal fluid and serum levels of cytokines and soluble tumour necrosis factor receptor in influenza virus-associated encephalopathy. Scand J Infect Dis 35:59-61

Ji Y, Lu H (2017) Malignancies in HIV-Infected and AIDS patients. Adv Exp Med Biol 1018:167-179. https://doi.org/10.1007/978981-10-5765-6_10

Jiang T, Zhou C, Ren S (2016) Role of IL-2 in cancer immunotherapy. Oncoimmunol 5:e1163462

Jiang S, Xia S, Ying T, Lu L (2020) A novel coronavirus (2019-nCoV) causing pneumonia-associated respiratory syndrome. Cell Mol Immunol 17:554. https://doi.org/10.1038/s41423-020-0372-4

Johnson RM, Vinetz JM (2020) Dexamethasone in the management of COVID-19. Brit Med J 370:m2648. https://doi.org/10.1136/ bmj.m2648

Kanwal R, Gupta K, Gupta S (2015) Cancer epigenetics: an introduction. Methods Mol Biol 1238:3-25. https://doi.org/10.1007/ 978-1-4939-1804-1_1

Karin N, Wildbaum G (2015) The role of chemokines in shaping the balance between CD4(+) T cell subsets and its therapeutic implications in autoimmune and cancer diseases. Front Immunol 6:609. https://doi.org/10.3389/fimmu.2015.00609

Kaufmann SHE (2019) Immunology's coming of age. Front Immunol 10:684. https://doi.org/10.3389/fimmu.2019.00684

Kawasaki T, Kawai T (2014) Toll-like receptor signaling pathways. Front Immunol 5:461. https://doi.org/10.3389/fimmu.2014.00461

Keith BD (2008) Systematic review of the clinical effect of glucocorticoids on nonhematologic malignancy. BMC Cancer 8:84. https:// doi.org/10.1186/1471-2407-8-84

Khalid M, Dernaika T, Jacob L, Annamaraju P, Guddati AK (2020) Weather the cytokine storm: a report of successful management of a colon cancer survivor and a critically ill patient with COVID-19. Case Rep Oncol 13:754-759. https://doi.org/10. $1159 / 000509507$
Khan S, Durairaj S (2020) JAK inhibition with methotrexate as treatment for COVID-19 is a double-edged sword. Int Arch Allergy Immunol 181:563-564. https://doi.org/10.1159/000508750

Kim-Schulze S, Taback B, Kaufman HL (2007) Cytokine therapy for cancer. Surg Oncol Clin N Am 16:793. https://doi.org/10.1016/j. soc.2007.07.011

Klein NC, Go CH, Cunha BA (2001) Infections associated with steroid use. Infect Dis Clin North Am 15:423. https://doi.org/10.1016/ s0891-5520(05)70154-9

Kuba K, Imai Y, Rao S, Gao H, Guo F, Guan B, Huan Y, Yang P, Zhang Y, Deng W, Bao L, Zhang B, Liu G, Wang Z, Chappell M, Liu Y, Zheng D, Leibbrandt A, Wada T, Slutsky AS, Penninger JM (2005) A crucial role of angiotensin converting enzyme 2 (ACE2) in SARS coronavirus-induced lung injury. Nat Med 11:875-879. https://doi.org/10.1038/nm1267

Kuderer NM, Choueiri TK, Shah DP, Shyr Y, Rubinstein SM, Rivera DR, Shete S, Hsu CY, Desai A, Limade Lopes LGGL Jr, Painter CA, Peters S, Thompson MA, Bakouny Z, Batist G, Bekaii-Saab T, Bilen MA, Bouganim N, Larroya MB, Castellano D, Del Prete SA, Doroshow DB, Egan PC, Elkrief A, Farmakiotis D, Flora D, Galsky MD, Glover MJ, Griffiths EA, Gulati AP, Gupta S, Hafez N, Halfdanarson TR, Hawley JE, Hsu E, Kasi A, Khaki AR, Lemmon CA, Lewis C, Logan B, Masters T, McKay RR, Mesa RA, Morgans AK, Mulcahy MF, Panagiotou OA, Peddi P, Pennell NA, Reynolds K, Rosen LR, Rosovsky R, Salazar M, Schmidt A, Shah SA, Shaya JA, Steinharter J, Stockerl-Goldstein KE, Subbiah S, Vinh DC, Wehbe FH, Weissmann LB, Wu JT, Wulff-Burchfield E, Xie Z, Yeh A, Yu PP, Zhou AY, Zubiri L, Mishra S, Lyman GH, Rini BI, Warner JL (2020) COVID-19 and Cancer Consortium. Clinical impact of COVID-19 on patients with cancer (CCC19): a cohort study. Lancet 395:1907-1918. https://doi.org/10.1016/S0140-6736(20)31187-9

Lagadinou M, Zareifopoulos N, Karela A, Kyriakopoulou O, Velissaris D (2020) Are patients with autoimmune disease at greater risk of developing severe COVID-19? J Clin Med Res 12:539-541. https://doi.org/10.14740/jocmr4245

Lagier JC, Million M, Gautret P, Colson P, Cortaredona S, GiraudGatineau A, Honoré S, Gaubert JY, Fournier PE, Tissot-Dupont $\mathrm{H}$, Chabrière E, Stein A, Deharo JC, Fenollar F, Rolain JM, Obadia Y, Jacquier A, La Scola B, Brouqui P, Drancourt M, Parola P, Raoult D. IHU COVID-19 Task force (2020) Outcomes of 3737 COVID-19 patients treated with hydroxychloroquine/azithromycin and other regimens in Marseille, France: a retrospective analysis. Travel Med Infect Dis 36:101791. https://doi.org/10. 1016/j.tmaid.2020.101791

Lan J, Ge J, Yu J, Shan S, Zhou H, Fan S, Zhang Q, Shi X, Wang Q, Zhang L, Wang X (2020) Structure of the SARS-CoV-2 spike receptor-binding domain bound to the ACE2 receptor. Nature 581:215-220. https://doi.org/10.1038/s41586-020-2180-5

Lee S, Margolin K (2011) Cytokines in cancer immunotherapy. Cancers 3:3856-3893. https://doi.org/10.3390/cancers3043856

Lee LYW, Cazier JB, Starkey T, Arnold R, Bisht V, Campton NA, Chackathayil J, Cheng VW, Curley HM, Fittall MW, FreemanMills L, Gennatas S, Goel A, Hartley S, Hughes DJ, Kerr D, Lee AJ, Lee RJ, McGrath SE, Middleton CP, Middleton G (2020) COVID-19 mortality in patients with cancer on chemotherapy or other anticancer treatments: a prospective cohort study. Lancet 395:1919-1926. https://doi.org/10.1016/S0140-6736(20)31173-9

Leggas M, Kuo KL, Robert F, Cloud G, deShazo M, Zhang R, Li M, Wang H, Davidson S, Rinehart J (2009) Intensive anti-inflammatory therapy with dexamethasone in patients with non-small cell lung cancer: effect on chemotherapy toxicity and efficacy. Cancer Chemother Pharmacol 63:731-743. https://doi.org/10. 1007/s00280-008-0767-x

Leonard BE (2015) Pain, depression and inflammation: are interconnected causative factors involved? Mod Trends 
Pharmacopsychiatry 30:22-35. https://doi.org/10.1159/00043 5930

Letto G (2020) SARS-CoV-2: reasons of epidemiology of severe ill disease cases and therapeutic approach using trivalent vaccine (tetanus, diphtheria and Bordetella pertussis). Med Hypotheses 141:109779. https://doi.org/10.1016/j.mehy.2020.109779

Levrero M, Zucman-Rossi J (2016) Mechanisms of HBV-induced hepatocellular carcinoma. J Hepatol 64:S84-S101. https://doi. org/10.1016/j.jhep.2016.02.021

Li X (2018) The inducers of immunogenic cell death for tumour immunotherapy. Tumouri 104:1-8. https://doi.org/10.5301/tj. 5000675

Li R, Lim A, Phoon MC, Narasaraju T, Ng JK, Poh WP, Sim MK, Chow VT, Locht C, Alonso S (2010) Attenuated Bordetella pertussis protects against highly pathogenic influenza $A$ viruses by dampening the cytokine storm. J Virol 84:7105-7113. https:// doi.org/10.1128/JVI.02542-09

Li Y, Cao F, Li M, Li P, Yu Y, Xiang L, Xu T, Lei J, Tai YY, Zhu J, Yang B, Jiang Y, Zhang X, Duo L, Chen P, Yu X (2018a) Hydroxychloroquine induced lung cancer suppression by enhancing chemo-sensitization and promoting the transition of M2-TAMs to M1-like macrophages. J Exp Clin Cancer Res 37:259. https://doi.org/10.1186/s13046-018-0938-5

Li R, Lin H, Ye Y, Xiao Y, Xu S, Wang J, Wang C, Zou Y, Shi M, Liang L, Xu H (2018b) Attenuation of antimalarial agent hydroxychloroquine on TNF- $\alpha$-induced endothelial inflammation. Int Immunopharmacol 63:261-269. https://doi.org/10.1016/j.intimp. 2018.08.008

Li H, Liu L, Zhang D, Xu J, Dai H, Tang N, Su X, Cao B (2020a) SARS-CoV-2 and viral sepsis: observations and hypotheses. Lancet. https://doi.org/10.1016/S0140-6736(20)30920-X

Li Q, Wu J, Nie J, Zhang L, Hao H, Liu S, Zhao C, Zhang Q, Liu H, Nie L, Qin H, Wang M, Lu Q, Li X, Sun Q, Liu J, Zhang L, Li X, Huang W, Wang Y (2020b) The impact of mutations in SARSCoV-2 spike on viral infectivity and antigenicity. Cell 182:12841294.e9. https://doi.org/10.1016/j.cell.2020.07.012

Liang W, Guan W, Chen R, Wang W, Li J, Xu K, Li C, Ai Q, Lu W, Liang H, Li S, He J (2020) Cancer patients in SARS-CoV-2 infection: a nationwide analysis in China. Lancet Oncol 21:335337. https://doi.org/10.1016/S1470-2045(20)30096-6

Lin HY (2020) The severe COVID-19: a sepsis induced by viral infection? And its immunomodulatory therapy. Chin J Traumatol 23:190-195. https://doi.org/10.1016/j.cjtee.2020.06.002

Lin KT, Wang LH (2016) New dimension of glucocorticoids in cancer treatment. Steroids 111:84-88. https://doi.org/10.1016/j.steroids. 2016.02.019

Liu Z, Ying Y (2020) The inhibitory effect of curcumin on virusinduced cytokine storm and its potential use in the associated severe pneumonia. Front Cell Dev Biol 8:479. https://doi.org/ 10.3389/fcell.2020.00479

Liu M, Yang Y, Gu C, Yue Y, Wu KK, Wu J, Zhu Y (2007) Spike protein of SARS-CoV stimulates cyclooxygenase-2 expression via both calcium-dependent and calcium-independent protein kinase C pathways. FASEB J 21:1586-1596. https://doi.org/10. 1096/fi.06-6589com

Liu B, Qu L, Yan S (2015) Cyclooxygenase-2 promotes tumour growth and suppresses tumour immunity. Cancer Cell Int 15:106. https:// doi.org/10.1186/s12935-015-0260-7

Liu Q, Zhou YH, Yang ZQ (2016) The cytokine storm of severe influenza and development of immunomodulatory therapy. Cell Mol Immunol 13:3-10. https://doi.org/10.1038/cmi.2015.74

Liu X, Long C, Xiong Q, Chen C, Ma J, Su Y, Hong K (2020a) Association of angiotensin converting enzyme inhibitors and angiotensin II receptor blockers with risk of COVID-19, inflammation level, severity, and death in patients with COVID-19: a rapid systematic review and meta-analysis. Clin Cardiol. https://doi. org/10.1002/clc.23421.10.1002/clc.23421

Liu C, Zhao Y, Okwan-Duodu D, Basho R, Cui X (2020b) COVID19 in cancer patients: risk, clinical features, and management. Cancer Biol Med 17:519-527. https://doi.org/10.20892/j.issn. 2095-3941.2020.0289

Lossignol D (2016) A little help from steroids in oncology. J Transl Intern Med 4:52-54. https://doi.org/10.1515/jtim-2016-0011

Lu H, Ouyang W, Huang C (2006) Inflammation, a key event in cancer development. Mol Cancer Res 4:221-233. https://doi.org/10. 1158/1541-7786.MCR-05-0261

Lukhna K, Cupido B, Hitzeroth J, Chin A, Ntsekhe M (2020) Cardiovascular care in sub-Saharan Africa during the COVID-19 crisis: lessons from the global experience. Cardiovasc J Afr 31:113-115

Luo W, Li YX, Jiang LJ, Chen Q, Wang T, Ye DW (2020) Targeting JAK-STAT signaling to control cytokine release syndrome in COVID-19. Trends Pharmacol Sci 41:531-543. https://doi.org/ 10.1016/j.tips.2020.06.007

Lyson K, Milenkovic K, McCann SM (1991) The stimulatory effect of interleukin-6 on corticotorpin releasing factor and thyrotropinreleasing hormone secretion in vitro. Prog Neuroendocrinol Immunol 4:161-165

Mallya RK, de Beer FC, Berry H, Hamilton ED, Mace BE, Pepys MB (1982) Correlation of clinical parameters of disease activity in rheumatoid arthritis with serum concentration of C-reactive protein and erythrocyte sedimentation rate. J Rheumatol 9:224-228

Mantovani A (1994) Tumour-associated macrophage in neoplastic progression a paradigm for the in vitro function of chemokines. Lab Investig 71:5-16

Mantovani A, Allavena P, Sica A, Balkwill F (2008) Cancer-related inflammation. Nature 454:436-444. https://doi.org/10.1038/natur $\mathrm{e} 07205$

Marovich M, Mascola JR, Cohen MS (2020) Monoclonal antibodies for prevention and treatment of COVID-19. JAMA 324:131-231. https://doi.org/10.1001/jama.2020.10245

Mateu-Salat M, Urgell E, Chico A (2020) SARS-COV-2 as a trigger for autoimmune disease: report of two cases of Graves' disease after COVID-19. J Endocrinol Investig 43:1527-1528. https:// doi.org/10.1007/s40618-020-01366-7

McAllister RM, Gilden RV, Green M (1972) Adenoviruses in human cancer. Lancet 1:831-833. https://doi.org/10.1016/s01406736(72)90812-4

Medzhitov R (2007) Recognition of microorganisms and activation of the immune response. Nature 449:819-826. https://doi.org/10. 1038/nature06246

Mégarbane B, Scherrmann JM (2020) Hydroxychloroquine and azithromycin to treat patients with COVID-19: both friends and foes? J Clinic Pharmacol 60:808-814. https://doi.org/10.1002/ jcph.1646

Meng J, Xiao G, Zhang J, He X, Ou M, Bi J, Yang R, Di W, Wang Z, Li Z, Gao H, Liu L, Zhang G (2020) Renin-angiotensin system inhibitors improve the clinical outcomes of COVID-19 patients with hypertension. Emerg Microbes Infect 9:757-760. https:// doi.org/10.1080/22221751.2020.1746200

Meo SA, Klonoff DC, Akram J (2020) Efficacy of chloroquine and hydroxychloroquine in the treatment of COVID-19. Eur Rev Med Pharmacol Sci 24:4539-4547. https://doi.org/10.26355/eurrev_ 202004_21038

Mizutani T (2009) Signaling pathways of SARS-CoV in vitro and in vivo. Mol Biol SARS Coronavirus. https://doi.org/10.1007/ 978-3-642-03683-5_19

Mizutani T, Fukushi S, Saijo M, Kurane I, Morikawa S (2005) JNK and PI3k/Akt signaling pathways are required for establishing persistent SARS-CoV infection in Vero E6 cells. Biochim Biophys Acta 1741:4-10. https://doi.org/10.1016/j.bbadis. 2005.04.004 
Mohamed-Hussein AAR, Aly KME, Ibrahim MAA (2020) Should aspirin be used for prophylaxis of COVID-19-induced coagulopathy? Med Hypoth 144:109975. https://doi.org/10.1016/j. mehy.2020.109975

Morishima Y, Mehta RK, Yoshimura M, Lau M, Southworth DR, Lawrence TS, Pratt WB, Nyati MK, Osawa Y (2018) Chaperone activity and dimerization properties of $\mathrm{Hsp} 90 \alpha$ and $\mathrm{Hsp} 90 \beta$ in glucocorticoid receptor activation by the multiprotein Hsp90/ Hsp70-dependent chaperone machinery. Mol Pharmacol 94:984991. https://doi.org/10.1124/mol.118.112516

Mosmann TR, Coffman RL (1989) TH1 and TH2 cells: different patterns of lymphokine secretion lead to different functional properties. Annu Rev Immunol 7:145-173. https://doi.org/10.1146/ annurev.iy.07.040189.001045

Muley MM, Krustev E, McDougall JJ (2016) Preclinical assessment of inflammatory pain. CNS Neurosci Ther 22:88-101. https://doi. org/10.1111/cns.12486

Müzes G, Sipos F (2015) Inflammasome, inflammation and cancer: an interrelated pathobiological triad. Curr Drug Targets 16:249257. https://doi.org/10.2174/1389450115666141229154157

Nakamura K, Smyth MJ (2017) Targeting cancer-related inflammation in the era of immunotherapy. Immunol Cell Biol 95:325-332. https://doi.org/10.1038/icb.2016.126

Navarra P, Tsagarakis S, Faria MS, Rees LH, Besser GM, Grossman AB (1991) Interleukins-1 and -6 stimulate the release of corticotropin-releasing hormone- 41 from rat hypothalamus in vitro via the eicosanoid cyclooxygenase pathway. Endocrinology 128:37-44. https://doi.org/10.1210/endo-128-1-37

Negus RPM, Balkwill FR (1996) Cytokines in tumour growth, migration and metastasis. World J Urol 14:157-165. https://doi.org/ 10.1007/BF00186895

Newton K, Dixit VM (2012) Signaling in innate immunity and inflammation. Cold Spring Harbor Perspect Biol 4:a006049. https://doi. org/10.1101/cshperspect.a006049

Nikolaou M, Pavlopoulou A, Georgakilas AG, Kyrodimos E (2018) The challenge of drug resistance in cancer treatment: a current overview. Clin Exp Metastasis 35:309-318. https://doi.org/10. 1007/s10585-018-9903-0

Nina PB, Dash AP (2020) Hydroxychloroquine as prophylaxis or treatment for COVID-19: what does the evidence say? Indian J Public Health 64:S125-S127. https://doi.org/10.4103/ijph.IJPH_496_20

Noah TL, Zhou H, Jaspers I (2012) Alteration of the nasal responses to influenza virus by tobacco smoke. Curr Opin Allergy Clin Immunol 12:24-31. https://doi.org/10.1097/ACI.0b013e32834ecc80

Omar S, Clarke R, Abdullah H, Brady C, Corry J, Winter H, Touzelet O, Power UF, Lundy F, McGarvey LP, Cosby SL (2017) Respiratory virus infection up-regulates TRPV1, TRPA1 and ASICS3 receptors on airway cells. PLoS One 12:e0171681. https://doi. org/10.1371/journal.pone.0171681

O’Neill L, Netea MG (2020) BCG-induced trained immunity: can it offer protection against COVID-19? Nat Rev Immunol 20:335337. https://doi.org/10.1038/s41577-020-0337-y

Oppenheim J, Fujiwara H (1996) The role of cytokines in cancer. Cytokine Growth Factor Rev 7:279-288. https://doi.org/10.1016/ s1359-6101(96)00025-1

Orlando BJ, Lucido MJ, Malkowski MG (2015) The structure of ibuprofen bound to cyclooxygenase-2. J Struct Biol 189:62-66. https://doi.org/10.1016/j.jsb.2014.11.005

O'Shea JJ, Laurence A, McInnes IB (2013) Back to the future: oral targeted therapy for RA and other autoimmune diseases. Nat Rev Rheumatol 9:173-182. https://doi.org/10.1038/nrrheum.2013.7

Paces J, Strizova Z, Smrz D, Cerny J (2020) COVID-19 and the immune system. Physiol Res 69:379-388. https://doi.org/10. 33549/physiolres.934492
Paintsil E (2020) COVID-19 threatens health systems in sub-Saharan Africa: the eye of the crocodile. J Clin Investig 130:2741-2744. https://doi.org/10.1172/JCI138493

Palomino DC, Marti LC (2015) Chemokines and immunity. Einstein (Sao Paulo) 13:469-473. https://doi.org/10.1590/S1679-45082 015RB3438

Pandya PH, Murray ME, Pollok KE, Renbarger JL (2016) The immune system in cancer pathogenesis: potential therapeutic approaches. J Immunol Res 2016:4273943. https://doi.org/10.1155/2016/ 4273943

Parkin J, Cohen B (2001) An overview of the immune system. Lancet 357:1777-1789. https://doi.org/10.1016/S0140-6736(00)04904-7

Patel DD, Kuchroo VK (2015) Th17 cell pathway in human immunity: lessons from genetics and therapeutic interventions. Immunity 43:1040-1051. https://doi.org/10.1016/j.immuni.2015.12.003

Pathan H, Williams J (2012) Basic opioid pharmacology: an update. Brit J Pain 6:11-16. https://doi.org/10.1177/2049463712438493

Penn I (1975) Malignant disease in immunodeficient states in man. Recent Results Cancer Res. https://doi.org/10.1007/978-3-64280940-8_12

Peters-Golden M, Henderson WR Jr (2007) Leukotrienes. N Engl J Med 357:1841-1854. https://doi.org/10.1056/NEJMra071371

Pfeifer GP (2020) Mechanisms of UV-induced mutations and skin cancer. Genome Instab Dis 1:99-113. https://doi.org/10.1007/ s42764-020-00009-8

Philip M, Rowley DA, Schreiber H (2004) Inflammation as a tumour promoter in cancer induction. Semin Cancer Biol 14:433-439. https://doi.org/10.1016/j.semcancer.2004.06.006

Pio R, Ajona D, Ortiz-Espinosa S, Mantovani A, Lambris JD (2019) Complementing the cancer-immunity cycle. Front Immunol 10:774. https://doi.org/10.3389/fimmu.2019.00774

Poonia B, Kottilil S (2020) Immune correlates of COVID-19 control. Front Immunol 11:569611. https://doi.org/10.3389/fimmu.2020. 569611

Poreba E, Broniarczyk JK, Gozdzicka-Jozefiak A (2011) Epigenetic mechanisms in virus-induced tumourigenesis. Clin Epigenet 2:233-247. https://doi.org/10.1007/s13148-011-0026-6

Poulin DL, DeCaprio JA (2006) Is there a role for SV40 in human cancer? J Clin Oncol 24:4356-4365. https://doi.org/10.1200/ JCO.2005.03.7101

Pradhan AD, Manson JE, Rifai N, Buring JE, Ridker PM (2001) C-reactive protein, interleukin 6 , and risk of developing type 2 diabetes mellitus. J Am Med Assoc 286:327-334. https://doi.org/ 10.1001/jama.286.3.327

Prasad K (2006) C-reactive protein (CRP)-lowering agents. Cardiovasc Drug Rev 24:33-50. https://doi.org/10.1111/j.1527-3466.2006. 00033.x

Principi N, Esposito S (2020) Chloroquine or hydroxychloroquine for prophylaxis of COVID-19. Lancet Infect Dis 20:1118. https:// doi.org/10.1016/S1473-3099(20)30296-6

Pufall MA (2015) Glucocorticoids and cancer. Adv Exp Med Biol 872:315-333. https://doi.org/10.1007/978-1-4939-2895-8_14

Radu O, Pantanowitz L (2013) Kaposi sarcoma. Arch Pathol Lab Med 137:289-294. https://doi.org/10.5858/arpa.2012-0101-RS

Rajaiah R, Abhilasha KV, Shekar MA, Vogel SN, Vishwanath BS (2020) Evaluation of mechanisms of action of re-purposed drugs for treatment of COVID-19. Cell Immunol 358:104240. https:// doi.org/10.1016/j.cellimm.2020.104240

Rathi S, Ish P, Kalantri A, Kalantri S (2020) Hydroxychloroquine prophylaxis for COVID-19 contacts in India. Lancet Infect Dis 20:1118-1119. https://doi.org/10.1016/S1473-3099(20)30313-3

Rayburn ER, Ezell SJ, Zhang R (2009) Anti-inflammatory agents for cancer therapy. Mol Cell Pharmacol 1:29-43. https://doi.org/10. 4255/mcpharmacol.09.05 
Read SA, Obeid S, Ahlenstiel C, Ahlenstiel G (2019) The role of zinc in antiviral immunity. Adv Nutr 10:696-710. https://doi.org/10. 1093/advances/nmz013

Reche PA (2020) Potential cross-reactive immunity to SARS-CoV-2 from common human pathogens and vaccines. Front Immunol 11:586984. https://doi.org/10.3389/fimmu.2020.586984

RECOVERY Collaborative Group, Horby P, Lim WS, Emberson JR, Mafham M, Bell JL, Linsell L, Staplin N, Brightling C, Ustianowski A, Elmahi E, Prudon B, Green C, Felton T, Chadwick D, Rege K, Fegan C, Chappell LC, Faust SN, Jaki T, Jeffery K, Montgomery A, Rowan K, Juszczak E, Baillie JK, Haynes R, Landray MJ (2020) Dexamethasone in hospitalized patients with COVID-19-preliminary report. N Engl J Med. https://doi.org/ 10.1056/NEJMoa2021436

Rider P, Carmi Y, Cohen I (2016) Biologics for targeting inflammatory cytokines, clinical uses, and limitations. Int J Cell Biol 2016:9259646. https://doi.org/10.1155/2016/9259646

Rinott E, Kozer E, Shapira Y, Bar-Haim A, Youngster I (2020) Ibuprofen use and clinical outcomes in COVID-19 patients. Clin Microbiol Infect. https://doi.org/10.1016/j.cmi.2020.06.003

Risch HA (2020) Early outpatient treatment of symptomatic, high-risk COVID-19 patients that should be ramped up immediately as key to the pandemic crisis. Am J Epidemiol 189:1218-1226. https:// doi.org/10.1093/aje/kwaa093

Rittirsch D, Flierl MA, Ward PA (2008) Harmful molecular mechanisms in sepsis. Nat Rev Immunol 8:776-787

Roche PA, Furuta K (2015) The ins and outs of MHC class II-mediated antigen processing and presentation. Nat Rev Immunol 15:203216. https://doi.org/10.1038/nri3818

Rodríguez-Perálvarez M, De la Mata M, Burroughs AK (2014) Liver transplantation: immunosuppression and oncology. Curr Opin Organ Transplant 19:253-260. https://doi.org/10.1097/MOT. 0000000000000069

Rotte A (2019) Combination of CTLA-4 and PD-1 blockers for treatment of cancer. J Exp Clin Cancer Res 38:255. https://doi.org/ 10.1186/s13046-019-1259-z

Rugge M, Zorzi M, Guzzinati S (2020) SARS-CoV-2 infection in the Italian Veneto region: adverse outcomes in patients with cancer. Nat Cancer 1:784-788

Russell B, Moss C, Rigg A, Van Hemelrijck M (2020) COVID-19 and treatment with NSAIDs and corticosteroids: should we be limiting their use in the clinical setting? Ecancermedicalscience 14:1023. https://doi.org/10.3332/ecancer.2020.1023

Sagara I, Oduro AR, Mulenga M, Dieng Y, Ogutu B, Tiono AB, Mugyenyi P, Sie A, Wasunna M, Kain KC, Djimdé AA, Sarkar S, Chandra R, Robbins J, Dunne MW (2014) Efficacy and safety of a combination of azithromycin and chloroquine for the treatment of uncomplicated Plasmodium falciparum malaria in two multi-country randomised clinical trials in African adults. Malar J 3:458. https://doi.org/10.1186/1475-2875-13-458

Sahu BR, Kampa RK, Padhi A, Panda AK (2020) C-reactive protein: a promising biomarker for poor prognosis in COVID-19 infection. Clin Chim Acta 509:91-94. https://doi.org/10.1016/j.cca. 2020.06.013

Saini KS, Lanza C, Romano M, de Azambuja E, Cortes J, de Las HB, de Castro J, Lamba Saini M, Loibl S, Curigliano G, Twelves C, Leone M, Patnaik MM (2020) Repurposing anticancer drugs for COVID-19-induced inflammation, immune dysfunction, and coagulopathy. Br J Cancer. https://doi.org/10.1038/ s41416-020-0948-x

Schädler D, Porzelius C, Jörres A, Marx G, Meier-Hellmann A, Putensen C, Quintel M, Spies C, Engel C, Weiler N, Kuhlmann M (2013) A multicenter randomized controlled study of an extracorporeal cytokine hemoadsorption device in septic patients. Crit Care 17(Suppl 2):P62. https://doi.org/10.1186/ cc12000
Schroeder HW Jr, Cavacini L (2010) Structure and function of immunoglobulins. J Allergy Clin Immunol 125:S41-S52. https://doi. org/10.1016/j.jaci.2009.09.046

Schulert GS, Grom AA (2015) Pathogenesis of macrophage activation syndrome and potential for cytokine- directed therapies. Annu Rev Med 66:145-159. https://doi.org/10.1146/annur ev-med-061813-012806

Schwartz DM, Kanno Y, Villarino A, Ward M, Gadina M, Tournier JJ (2017) JAK inhibition as a therapeutic strategy for immune and inflammatory diseases. Nat Rev Drug Discov 16:843-862. https://doi.org/10.1038/nrd.2017.201

Schwiebert LM, Beck LA, Stellato C, Bickel CA, Bochner BS, Schleimer RP (1996) Glucocorticosteroid inhibition of cytokine production: relevance to antiallergic actions. J Allergy Clin Immunol 97:143-152

Sedger LM, McDermott MF (2014) TNF and TNF-receptors: From mediators of cell death and inflammation to therapeutic giants past, present and future. Cytokine Growth Factor Rev 25:453472. https://doi.org/10.1016/j.cytogfr.2014.07.016

Sedokani A, Feizollahzadeh S (2020) Plasmapheresis, anti-ACE2 and anti-Fc $\gamma$ RII monoclonal antibodies: a possible treatment for severe cases of COVID-19. Drug Des Dev Ther 14:26072611. https://doi.org/10.2147/DDDT.S262491

Seif F, Aazami H, Khoshmirsafa M, Kamali M, Mohsenzadegan M, Pornour M, Mansouri D (2020) JAK inhibition as a new treatment strategy for patients with COVID-19. Int Arch Allergy Immunol 181:467-475. https://doi.org/10.1159/000508247

Seliger B (2005) Strategies of tumour immune evasion. BioDrugs 19:347-354. https://doi.org/10.2165/00063030-20051 9060-00002

Sereda D, Werth VP (2006) Improvement in dermatomyositis rash associated with the use of antiestrogen medication. Arch Dermatol 142:70-72. https://doi.org/10.1001/archderm.142.1.70

Sewell HF, Agius RM, Kendrick D, Stewart M (2020) Vaccines, convalescent plasma, and monoclonal antibodies for COVID-19. BMJ 370:m2722. https://doi.org/10.1136/bmj.m2722

Shanmugaraj B, Siriwattananon K, Wangkanont K, Phoolcharoen W (2020) Perspectives on monoclonal antibody therapy as potential therapeutic intervention for Coronavirus disease-19 (COVID-19). Asian Pac J Allergy Immunol 38:10-18. https:// doi.org/10.12932/AP-200220-0773

Shanthanna H, Strand NH, Provenzano DA, Lobo CA, Eldabe S, Bhatia A, Wegener J, Curtis K, Cohen SP, Narouze S (2020) Caring for patients with pain during the COVID-19 pandemic: consensus recommendations from an international expert panel. Anaesthesia 75:935-944

Sharma M (2015) Chemokines and their receptors: orchestrating a fine balance between health and disease. Crit Rev Biotechnol 30:1-22. https://doi.org/10.1080/07388550903187418

Sharun K, Dhama K, Patel SK, Pathak M, Tiwari R, Singh BR, Sah R, Bonilla-Aldana DK, Rodriguez-Morales AJ, Leblebicioglu H (2020) Ivermectin, a new candidate therapeutic against SARS-CoV-2/COVID-19. Ann Clin Microbiol Antimicrob 19:23. https://doi.org/10.1186/s12941-020-00368-w

Shaw AC, Goldstein DR, Montgomery RR (2013) Age-dependent dysregulation of innate immunity. Nat Rev Immunol 13:875-887

Shiau S, Krause KD, Valera P, Swaminathan S, Halkitis PN (2020) The Burden of COVID-19 in people living with HIV: a syndemic perspective. AIDS Behav 24:2244-2249. https://doi.org/10.1007/ s10461-020-02871-9

Shorr AF, Abbott KC, Agadoa LY (2003) Acute respiratory distress syndrome after kidney transplantation: epidemiology, risk factors, and outcomes. Crit Care Med 31:1325-1330. https://doi. org/10.1097/01.CCM.0000053645.38356.A6 
Singh R, Mishra MK, Aggarwal H (2017) Inflammation, immunity, and cancer. Mediat Inflamm 2017:6027305. https://doi.org/10. 1155/2017/6027305

Singh Y, Gupta G, Satija S, Pabreja K, Chellappan DK, Dua K (2020) COVID-19 transmission through host cell directed network of GPCR. Drug Dev Res 81:647-649. https://doi.org/10.1002/ddr. 21674

Slimano F, Baudouin A, Zerbit J, Toulemonde-Deldicque A, ThomasSchoemann A, Chevrier R, Daouphars M, Madelaine I, Pourroy B, Tournamille JF, Astier A, Ranchon F, Cazin JL, Bardin C, Rioufol C (2020) Cancer, immune suppression and Coronavirus Disease-19 (COVID-19): need to manage drug safety (French Society for Oncology Pharmacy [SFPO] guidelines). Cancer Treat Rev 88:102063. https://doi.org/10.1016/j.ctrv.2020.102063

Smatti MK, Cyprian FS, Nasrallah GK, Al Thani AA, Almishal RO, Yassine HM (2019) Viruses and autoimmunity: a review on the potential interaction and molecular mechanisms. Viruses 11:762. https://doi.org/10.3390/v11080762

Smyk W, Janik MK, Portincasa P, Milkiewicz P, Lammert F, Krawczyk M (2020) COVID-19: focus on the lungs but do not forget the gastrointestinal tract. Eur J Clin Investig. https://doi.org/10. 1111/eci.13276

Song P, Li W, Xie J, Hou Y, You C (2020) Cytokine storm induced by SARS-CoV-2. Clin Chim Acta 509:280-287. https://doi.org/10. 1016/j.cca.2020.06.017

Stebbing J, Phelan A, Griffin I, Tucker C, Oechsle O, Smith D, Richardson P (2020) COVID-19: combining antiviral and anti-inflammatory treatments. Lancet Infect Dis 20:400-402. https://doi.org/ 10.1016/S1473-3099(20)30132-8

Steele VE, Holmes CA, Hawk ET, Kopelovich L, Lubet RA, Crowell JA, Sigman CC, Kelloff GJ (1999) Lipoxygenase inhibitors as potential cancer chemopreventives. Cancer Epidemiol Biomark Prev 8:467-483

Suarez-Almazor ME, Spooner C, Belseck E (2000) Azathioprine for rheumatoid arthritis. Cochrane Database Syst Rev. https://doi. org/10.1002/14651858.CD001461

Sun J, Aghemo A, Forner A, Valenti L (2020) COVID-19 and liver disease. Liver Int 40:1278-1281. https://doi.org/10.1111/liv.14470

Sweitzer NK (2003) Cardiology patient page. What is an angiotensin converting enzyme inhibitor? Circulation 108:e16-e18. https:// doi.org/10.1161/01.CIR.0000075957.16003.07

Temin HM, Mizutani S (1970) RNA-dependent DNA polymerase in virions of Rous sarcomavirus. Nature 226:1211-1213. https:// doi.org/10.1038/2261211a0

Thun MJ, Henley SJ, Patrono C (2002) Nonsteroidal anti-inflammatory drugs as anticancer agents: mechanistic, pharmacologic, and clinical issues. J Natl Cancer Inst 94:252-266. https://doi.org/ 10.1093/jnci/94.4.252

Tisoncik JR, Korth MJ, Simmons CP, Farrar J, Martin TR, Katze MG (2012) Into the eye of the cytokine storm. Microbiol Mol Biol Rev 76:16-32. https://doi.org/10.1128/MMBR.05015-11

Tominaga M, Julius D (2000) Capsaicin receptor in the pain pathway. Jpn J Pharmacol 83:20-24. https://doi.org/10.1254/jjp.83.20

Tournier C (2013) The 2 faces of JNK signaling in cancer. Genes Cancer 4:397-400. https://doi.org/10.1177/1947601913486349

Treon SP, Castillo JJ, Skarbnik AP, Soumerai JD, Ghobrial IM, Guerrera ML, Meid K, Yang G (2020) The BTK inhibitor ibrutinib may protect against pulmonary injury in COVID-19-infected patients. Blood 135:1912-1915. https://doi.org/10.1182/blood. 2020006288

Tugues S, Burkhard SH, Ohs I, Vrohlings M, Nussbaum K, Vom Berg J, Kulig P, Becher B (2014) New insights into IL-12-mediated tumour suppression. Cell Death Diff 22:237-246. https://doi.org/ 10.1038/cdd.2014.134

Turner MD, Nedjai B, Hurst T, Pennington DJ (2014) Cytokines and chemokines: at the crossroads of cell signalling and inflammatory disease. Biochim Biophys Acta 1843:2563-2582. https://doi.org/ 10.1016/j.bbamcr.2014.05.014

Turnquist C, Ryan BM, Horikawa I, Harris BT, Harris CC (2020) Cytokine storms in cancer and COVID-19. Cancer Cell 38:598601. https://doi.org/10.1016/j.ccell.2020.09.019

Uciechowski P, Dempke WCM (2020) Interleukin-6: a masterplayer in the cytokine network. Oncology 98:131-137. https://doi.org/ $10.1159 / 000505099$

Uno Y (2020) Why does SARS-CoV-2 invade the gastrointestinal epithelium? Gastroenterology 159:1622-1623. https://doi.org/10. 1053/j.gastro.2020.04.006

van Dorp L, Acman M, Richard D, Shaw LP, Ford CE, Ormond L, Owen CJ, Pang J, Tan CCS, Boshier FAT, Ortiz AT, Balloux F (2020) Emergence of genomic diversity and recurrent mutations in SARS-CoV-2. Infect Genet Evol 83:104351. https://doi.org/ 10.1016/j.meegid.2020.104351

van Horssen R, Ten Hagen TL, Eggermont AM (2006) TNF-alpha in cancer treatment: molecular insights, antitumour effects, and clinical utility. Oncologist 11:397-408. https://doi.org/10.1634/ theoncologist.11-4-397

Vandewalle J, Luypaert A, De Bosscher K, Libert C (2018) Therapeutic mechanisms of glucocorticoids. Trends Endocrinol Metab 29:42-54. https://doi.org/10.1016/j.tem.2017.10.010

Vanneman M, Dranoff G (2012) Combining immunotherapy and targeted therapies in cancer treatment. Nat Rev Cancer 12:237-251. https://doi.org/10.1038/nrc3237

Varela ML, Mogildea M, Moreno I, Lopes A (2018) Acute inflammation and metabolism. Inflammation 41:1115-1127. https://doi. org/10.1007/s10753-018-0739-1

Vasan N, Baselga J, Hyman DM (2019) A view on drug resistance in cancer. Nature 575:299-309. https://doi.org/10.1038/ s41586-019-1730-1

Vatansev H, Kadiyoran C, Cumhur Cure M, Cure E (2020) COVID19 infection can causechemotherapy resistance development in patients with breast cancer and tamoxifen may cause susceptibility to COVID-19 infection. Med Hypotheses 143:110091. https:// doi.org/10.1016/j.mehy.2020.110091

Vaz AP, Morais A, Melo N, Caetano Mota P, Souto Moura C, Amorim A (2011) Azitromicina como terapêutica adjuvante na pneumonia organizativa criptogénica [Azithromycin as an adjuvant therapy in cryptogenic organizing pneumonia]. Rev Port Pneumol 17:186-189. https://doi.org/10.1016/j.rppneu.2011.03.010

Vilcek J, Feldmann M (2004) Historical review: cytokines as therapeutics and targets of therapeutics. Trends Pharmacol Sci 25:201209. https://doi.org/10.1016/j.tips.2004.02.011

Vinay DS, Kwon BS (2018) Harnessing immune checkpoints for cancer therapy. Immunotherapy 10:1265-1284. https://doi.org/10.2217/ imt-2017-0168

Vinay DS, Ryan EP, Pawelec G, Talib WH, Stagg J, Elkord E, Lichtor T, Decker WK, Whelan RL, Kumara HMCS, Signori E, Honoki K, Georgakilas AG, Amin A, Helferich WG, Boosani CS, Guha G, Ciriolo MR, Chen S, Mohammed SI, Azmi AS, Keith WN, Bilsland A, Bhakta D, Halicka D, Fujii H, Aquilano K, Ashraf SS, Nowsheen S, Yang X, Choi BK, Kwon BS (2015) Immune evasion in cancer: mechanistic basis and therapeutic strategies. Semin Cancer Biol 35(Suppl):S185-S198. https://doi.org/10. 1016/j.semcancer.2015.03.004

Vincent MJ, Bergeron E, Benjannet S, Erickson BR, Rollin PE, Ksiazek TG, Seidah NG, Nichol ST (2005) Chloroquine is a potent inhibitor of SARS coronavirus infection and spread. Virol J 2:69. https://doi.org/10.1186/1743-422X-2-69

Vishvkarma R, Rajender S (2020) Could SARS-CoV-2 affect male fertility? Andrologia 52:e13712. https://doi.org/10.1111/and.13712

Vogt PK (1997) Historical introduction to the general properties of retroviruses. In: Coffin JM, Hughes SH, Varmus HE (eds) 
Retroviruses. Cold Spring Harbor Laboratory Press, Cold Spring Harbor, pp 1-25

Vogt PK (2012) Retroviral oncogenes: a historical primer. Nat Rev Cancer 12:639-648. https://doi.org/10.1038/nrc3320

Walker PG, White MT, Griffin JT, Reynolds A, Ferguson NM, Ghani AC (2015) Malaria morbidity and mortality in Ebola-affected countries caused by decreased health-care capacity, and the potential effect of mitigation strategies: a modelling analysis. Lancet Infect Dis 15:825-832. https://doi.org/10.1016/S14733099(15)70124-6

Wander P, Epstein M, Bernstein D (2020) COVID-19 Presenting As Acute Hepatitis. Amer J Gastroenterol 115:941-942. https://doi. org/10.14309/ajg.0000000000000660

Wang H, Zhang L (2020) Risk of COVID-19 for patients with cancer. Lancet Oncol 21:e181. https://doi.org/10.1016/S1470-2045(20) 30149-2

Wang W, Liu L, Zhou Y, Ye Q, Yang X, Jiang J, Ye Z, Gao F, Tan X, Zhang G, Fang Q, Xuan ZX (2019) Hydroxychloroquine enhances the antitumour effects of BC001 in gastric cancer. Int J Oncol 55:405-414. https://doi.org/10.3892/ijo.2019.4824

Wang J, Jiang M, Chen X, Montaner LJ (2020c) Cytokine storm and leukocyte changes in mild versus severe SARS-CoV-2 infection: review of 3939 COVID-19 patients in China and emerging pathogenesis and therapy concepts. J Leuk Biol 108:17-41. https://doi. org/10.1002/JLB.3COVR0520-272R

Wang T, Du Z, Zhu F, Cao Z, An Y, Gao Y, Jiang B (2020d) Comorbidities and multi-organ injuries in the treatment of COVID-19. Lancet 395(10228):e52. https://doi.org/10.1016/S0140-6736(20) 30558-4

Wang EY, Mao T, Klein J, Dai Y, Huck JD, Liu F, Zheng NS, Zhou T, Israelow B, Wong P, Lucas C, Silva J, Oh JE, Song E, Perotti ES, Fischer S, Campbell M, Fournier JB, Wyllie AL, Vogels CBF, Ott IM, Kalinich CC, Petrone ME, Watkins AE, Cruz CD, Farhadian SF, Schulz WL, Grubaugh ND, Ko AI, Iwasaki A, Ring AM (2020a) Diverse functional autoantibodies in patients with COVID-19. medRxiv. https://doi.org/10.1101/2020.12.10. 20247205

Wang G, Wu C, Zhang Q, Wu F, Yu B, Lv J, Li Y, Li T, Zhang S, Wu C, Wu G, Zhong Y (2020b) C reactive protein level may predict the risk of COVID-19 aggravation. Open Forum Infect Dis. https://doi.org/10.1093/ofid/ofaa153

Ward RA, Fawell S, Floc'h N, Flemington V, McKerrecher D, Smith PD (2020) Challenges and opportunities in cancer drug resistance. Chem Rev. https://doi.org/10.1021/acs.chemrev.0c00383

Watkins LR, Milligan ED, Maier SF (2003) Glial pro-inflammatory cytokines mediate exaggerated pain states: implications for clinical pain. Adv Exp Med Biol 521:1-21

Weatherford L, Lehn M, Crist M, Wendling C, Hudock K, Takiar V, Wise-Draper T (2020) Abstract S02-03: SARS-CoV-2 induces inflammatory cytokine release, which may be exacerbated by immune checkpoint blockade. Clin Cancer Res 26:S02-03. https://doi.org/10.1158/1557-3265.COVID-19-S02-03

Werz O, Steinhilber D (2006) Therapeutic options for 5-lipoxygenase inhibitors. Pharmacol Ther 112:701-718. https://doi.org/10. 1016/j.pharmthera.2006.05.009

White MK, Pagano JS, Khalili K (2014b) Viruses and human cancers: a long road of discovery of molecular paradigms. Clin Microbiol Rev 27:463-481. https://doi.org/10.1128/CMR.00124-13

White MC, Holman DM, Boehm JE, Peipins LA, Grossman M, Henley SJ (2014a) Age and cancer risk: a potentially modifiable relationship. Am J Pre Med 46:S7-S15. https://doi.org/10.1016/j. amepre.2013.10.029

Williams C, Mann M, DuBois R (1999) The role of cyclooxygenases in inflammation, cancer, and development. Oncogene 18:79087916. https://doi.org/10.1038/sj.onc. 1203286
Wingrove C, Ferrier L, James C, Wang S (2020) The impact of COVID-19 on hepatitis elimination. Lancet Gastroenterol Hepatol 5:792-794. https://doi.org/10.1016/S2468-1253(20)30238-7

World Health Organization (2019) World malaria report. World Health Organization, Geneva

Wöss K, Simonović N, Strobl B, Macho-Maschler S, Müller M (2019) TYK2: an upstream kinase of STATs in cancer. Cancers 11:1728. https://doi.org/10.3390/cancers11111728

Wu C, Chen X, Cai Y, Xia J, Zhou X, Xu S, Huang H, Zhang L, Zhou X, Du C, Zhang Y, Song J, Wang S, Chao Y, Yang Z, Xu J, Zhou X, Chen D, Xiong W, Xu L, Song Y (2020b) Risk factors associated with acute respiratory distress syndrome and death in patients with coronavirus disease 2019 pneumonia in Wuhan, China. JAMA Intern Med. https://doi.org/10.1001/jamaintern med.2020.0994

Wu Q, Wu W, Jacevic V, Franca TCC, Wang X, Kuca K (2020a) Selective inhibitors for JNK signalling: a potential targeted therapy in cancer. J Enzyme Inhib Med Chem 35:574-583. https://doi.org/ 10.1080/14756366.2020.1720013

Xiang Z, Liu J, Shi D, Chen W, Li J, Yan R, Bi Y, Hu W, Zhu Z, Yu Y, Yang Z (2020) Glucocorticoids improve severe or critical COVID-19 by activating ACE2 and reducing IL-6 levels. Int J Biol Sci 16:2382-2391. https://doi.org/10.7150/ijbs.47652

Xiao F, Tang M, Zheng X, Liu Y, Li X, Shan H (2020) Evidence for gastrointestinal infection of SARS-CoV-2. Gastroenterology 158:1831-1833. https://doi.org/10.1053/j.gastro.2020.02. $055(\mathbf{e} 3)$

Xue J, Moyer A, Peng B, Wu J, Hannafon BN, Ding WQ (2014) Chloroquine is a zinc ionophore. PLoS One 9(10):e109180. https:// doi.org/10.1371/journal.pone.0109180

Yang M, Chen X, Xu Y (2020a) A retrospective study of the C-reactive protein to lymphocyte ratio and disease severity in 108 patients with early COVID-19 pneumonia from January to March 2020 in Wuhan, China. Med Sci Monit Int Med J Exp Clin Res 26:e926393. https://doi.org/10.12659/MSM.926393

Yang Z, Liu J, Zhou Y, Zhao X, Zhao Q, Liu J (2020b) The effect of corticosteroid treatment on patients with coronavirus infection: a systematic review and meta-analysis. J Infect 81:e13-e20. https:// doi.org/10.1016/j.jinf.2020.03.062

Yao X, Huang J, Zhong H, Shen N, Faggioni R, Fung M, Yao Y (2014) Targeting interleukin-6 in inflammatory autoimmune diseases and cancers. Pharmacol Ther 141:125-139. https://doi.org/10. 1016/j.pharmthera.2013.09.004

Yao X, Ye F, Zhang M, Cui C, Huang B, Niu P, Liu X, Zhao L, Dong E, Song C, Zhan S, Lu R, Li H, Tan W, Liu D (2020) In vitro antiviral activity and projection of optimized dosing design of hydroxychloroquine for the treatment of severe acute respiratory syndrome coronavirus 2 (SARS-CoV-2). Clin Infect Dis 71:732-739. https://doi.org/10.1093/cid/ciaa237

Yarchoan R, Uldrick TS (2018) HIV-associated cancers and related diseases. N Engl J Med 378:1029-1041. https://doi.org/10.1056/ NEJMra1615896

Ye Q, Wang B, Mao J (2020) The pathogenesis and treatment of the 'Cytokine Storm'' inCOVID-19.' J Infect 80:607-613. https:// doi.org/10.1016/j.jinf.2020.03.037

Yeo NK, Park WJ, Eom DW, Oh MY, Lee JH (2019) Effects of azathioprine and its metabolites on inflammatory cytokines in human nasal polyp organ cultures. Int Forum Allergy Rhinol 9:648-655. https://doi.org/10.1002/alr.22303

Yiğenoğlu TN, Hacıbekiroğlu T, Berber İ, Dal MS, Baştürk A, Namdaroğlu S, Korkmaz S, Ulas T, Dal T, Erkurt MA, Turgut B, Altuntaş F (2020) Convalescent plasma therapy in patients with COVID-19. J Clin Apher 35:367-373. https://doi.org/10. $1002 /$ jca. 21806

Yokota S (2003) Influenza-associated encephalopathy-pathophysiology and disease mechanisms. Nihon Rinsho 61:1953-1958 
Yoshimura A, Kinjyo I, Inagaki-Ohara K, Hanada T (2003) STAT/ SOCS family members in inflammation and diseases. In: Sehgal PB, Levy DE, Hirano T (eds) Signal transducers and activators of transcription (STATs). Springer, Dordrecht. https://doi.org/10. 1007/978-94-017-3000-6_34

Zappavigna S, Cossu AM, Grimaldi A, Bocchetti M, Ferraro GA, Nicoletti GF, Filosa R, Caraglia M (2020) Anti-inflammatory drugs as anticancer agents. Int J Mol Sci 21:2605. https://doi.org/10. 3390/ijms 21072605

Zawawi A, Alghanmi M, Alsaady I, Gattan H, Zakai H, Couper K (2020) The impact of COVID-19 pandemic on malaria elimination. Parasite Epidemiol Control 11:e00187. https://doi.org/10. 1016/j.parepi.2020.e00187

Zha L, Li S, Pan L, Tefsen B, Li Y, French N, Chen L, Yang G, Villanueva EV (2019) Corticosteroid treatment of patients with coronavirus disease 2019 (COVID-19). Med J Aust 212:416-420. https://doi.org/10.5694/mja2.50577

Zhang JM, An J (2007) Cytokines, inflammation, and pain. Int Anesth Clin 45:27-37. https://doi.org/10.1097/AIA.0b013e318034194e

Zhang C, Wang Y, Fu W, Zhang W, Wang T, Qin H (2016) A metaanalysis on the effect of ulinastatin on serum levels of C-reactive protein, interleukin 6, and tumor necrosis factor alpha in Asian patients with acute pancreatitis. Genet Test Mol Biomarkers 20:118-124. https://doi.org/10.1089/gtmb.2015.0192

Zhang W, Zhao Y, Zhang F, Wang Q, Li T, Liu Z, Wang J, Qin Y, Zhang X, Yan X, Zeng X, Zhang S (2020a) The use of antiinflammatory drugs in the treatment of people with severe coronavirus disease 2019 (COVID-19): the perspectives of clinical immunologists from China. Clin Immunol (Orlando, Fla) 214:108393. https://doi.org/10.1016/j.clim.2020.108393

Zhang L, Zhu F, Xie L, Wang C, Wang J, Chen R, Jia P, Guan HQ, Peng L, Chen Y, Peng P, Zhang P, Chu Q, Shen Q, Wang Y, Xu SY, Zhao JP, Zhou M (2020b) Clinical characteristics of COVID19-infected cancer patients: a retrospective case study in three hospitals within Wuhan. China Ann Oncol 31:894-901. https:// doi.org/10.1016/j.annonc.2020.03.296
Zheng M, Huang J, Tong A, Yang H (2019) Oncolytic viruses for cancer therapy: barriers and recent advances. Mol Ther Oncolytics 15:234-247. https://doi.org/10.1016/j.omto.2019.10.007

Zheng YY, Ma YT, Zhang JY, Xie X (2020) COVID-19 and the cardiovascular system. Nat Rev Cardiol 17:259-260. https://doi.org/ 10.1038/s41569-020-0360-5

Zhou C, Tuong ZK, Frazer IH (2019) Papillomavirus immune evasion strategies target the infected cell and the local immune system. Front Oncol 9:682. https://doi.org/10.3389/fonc.2019.00682

Zhou Y, Fu B, Zheng X, Wang D, Zhao C, Qi Y, Sun R, Tian Z, Xu X, Wei H (2020b) Pathogenic T-cells and inflammatory monocytes incite inflammatory storms in severeCOVID-19 patients. Nation Sci Rev 7:998-1002. https://doi.org/10.1093/nsr/nwaa041

Zhou F, Yu T, Du R, Fan G, Liu Y, Liu Z, Xiang J, Wang Y, Song B, Gu X, Guan L, Wei Y, Li H, Wu X, Xu J, Tu S, Zhang Y, Chen H, Cao B (2020a) Clinical course and risk factors for mortality of adult inpatients with COVID-19 in Wuhan, China: a retrospective cohort study. Lancet 395:1054-1062. https://doi.org/10. 1016/S0140-6736(20)30566-3

Zhu K, Liu Q, Zhou Y, Tao C, Zhao Z, Sun J, Xu H (2015) Oncogenes and tumour suppressor genes: comparative genomics and network perspectives. BMC Genom 16:S8. https://doi.org/10.1186/ 1471-2164-16-S7-S8

Zolk O, Hafner S, Schmidt CQ (2020) German Society for Experimental and Clinical Pharmacology and Toxicology (DGPT). COVID19 pandemic and therapy with ibuprofen or renin-angiotensin system blockers: no need for interruptions or changes in ongoing chronic treatments. Naunyn Schmiedebergs Arch Pharmacol 393:1131-1135. https://doi.org/10.1007/s00210-020-01890-6

Publisher's Note Springer Nature remains neutral with regard to jurisdictional claims in published maps and institutional affiliations. 